Iryna Kachur

Oddział Książki Rzadkiej i Starych Druków

Lwowskiej Narodowej Naukowej Biblioteki Ukrainy im. Wasyla Stefanyka, Lwów, Ukraina ira-kachur@ukr.net

ORCID 0000-0003-3909-3489

http://doi.org/10.33077/zbkh.2018.12.kachur

\title{
Autorskie autografy na egzemplarzach starych druków XVI-XVIII w., zachowanych we Lwowskiej Narodowej Naukowej Bibliotece Ukrainy im. Wasyla Stefanyka
}

\begin{abstract}
Author's autographs in the early printed books of the 16-18 ${ }^{\text {th }}$ centuries of the Vasyl Stefanyk Lviv National Scientific Library of Ukraine
\end{abstract}

The author's autographs in the early printed books from the collection of the Vasyl Stefanyk Lviv National Scientific Library of Ukraine can be grouped in two categories. The first one includes author's signatures, their individual notes concerning the book, amendments and supplements to the text. These materials, quite rare in the books, are of particular importance for the researchers of the history of writing and printing. They can become an authoritative reference for dating, settling authorship of anonymous works, preparations of critical editions. The following authors are mentioned in the text: Mikołaj Bernett (1643-1710), Stanisław Brzeżański (ca 1650-1738), Tadeusz Juda Krusiński (1675-1757), Gottfried Lengnich (16891774), Ignacy Krasicki (1735-1801). The other category of author's autographs, bigger and as precious as the previous one, includes hand-written author's dedications. The annex to this text registers 67 Polish dedications from the $16-18^{\text {th }}$ centuries. The following famous persons can be found among authors and recipients: Erazm of Rotterdam, Ercole Sassonia, Martinus Glicius of Pilzno, Andrzej Wolan, and Daniel Mikołajewski.

Key words: early printed book - handwritten author's inscription - autograph - dedication Ossolineum - Vasyl Stefanyk Lviv National Scientific Library of Ukraine.

Słowa kluczowe: stare druki - własnoręczny autorski zapis - autograf - dedykacja Ossolineum - Lwowska Narodowa Naukowa Biblioteka Ukrainy im. Wasyla Stefanyka. 
Lwowska Narodowa Naukowa Biblioteka Ukrainy im. W. Stefanyka (LNNBU; Львівська національна наукова бібліотека України імені В. Стефаника) wskutek nacjonalizacji i centralizacji księgozbiorów w latach 40. XX w. skupiła zbiory instytucjonalnych, klasztornych i prywatnych bibliotek, istniejących wówczas we Lwowie oraz we wschodniej Galicji. W wyniku wielokierunkowych badań zasobu starych druków, liczącego obecnie 120000 woluminów, zostały ujawnione dwa typy autografów, pozostawionych przez autorów na książkach XVI-XVIII w.

Do pierwszego zaliczamy ich podpisy, własnoręczne zapiski dotyczące druku, poprawki oraz uzupełnienia w drukowanym tekście. Materiały tego rodzaju, dość rzadko spotykane w książkach, mają szczególne znaczenie dla badaczy historii piśmiennictwa i drukarstwa, stanowią wiarygodną podstawę datowania i ustalenia autorstwa anonimowych dzieł oraz przygotowania do publikacji ich krytycznych wydań.

Do takich autografów należy skromny podpis „Wasz M[ości] M[ości] Panstwa Vnizony sługa X[iądz] Mikołay Bernett Societ[atis] Jesu Auctor f[idelis]" pod drukowaną dedykacją w wydaniu żywota Marianny z Kazanowskich Jabłonowskiej ${ }^{1}$, który ujawnia autora tego bezimiennie wydrukowanego dzieła - jezuitę, profesora, kaznodzieję i prefekta jezuickiej biblioteki we Lwowie Mikołaja Bernetta (Bernet, 1643-1710). Oprócz naszego druku prawdziwość tej informacji potwierdza podobny zapis na egzemplarzu tej edycji z Biblioteki Jagiellońskiej, wymienionym przez Karola Estreichera.

Autorską notatkę i korektę tekstu znajdujemy również w dwóch zachowanych w naszej bibliotece egzemplarzach utworu Stanisława Brzeżańskiego (ok. 1650-1738) Owczarnia W Dzikim Polu..., wytłoczonego w 1717 r. we lwowskiej drukarni jezuitów ${ }^{2}$. Na dole kart tytułowych autor wyjaśnia powód, dla którego zostały sporządzone:

Xięga ta dla ratunku wielkich potrzeb Koscioła Busczeckiego podana do druku, wyszła z niego mylno barzo, dla niespodziwaney odmiany dyrektora drukarni. Poprawiona tedy iest ręką cudzą, iednakże sposobiąc ią iako naydoskonaley w ręce Dobrodzieyskie znowu sam rewidowałem y dostatecznie ią poprawiłem. Xiądz Stanisław z Brzezanki Brzezanskj Dziekan Dunajowski Pleban Busczeckj.

Umieszczona $\mathrm{w}$ tym zapisie informacja o zmianie prefekta typografii w 1717 r. uzupełnia naszą wiedzę o mało znanym okresie jej działalności,

[M. Bernett], Obraz Swiatobliwego Zycia ... Maryi Anny z Kazanowa Jablonowskiey Woiewodziney i Generatowey Ziem Ruskich Hetmanowey W. Koronney Przez Kaplana Soc: Jesu Przy zwyczaynym dorocznym obchodzie W Roku 1696 W Kollegium Lwowskim Wystawiony, [Lwów: druk. Collegium Soc. Jesu, 1696.]; 8. E. XII, 505-506; sygn. LNNBU: CT-I 118149.

2 S. Brzeżański, Owczarnia W Dzikim Polu ... To iest Katechyzm Polski z przyczyn w Informacyi wyrażonych Piesniami Wydany, [Lwów:] w Drukarni Kollegium Lwowskiego Societatis Jesu, [post 25 V] 1717; 4․ E. XIII, 390; sygn. LNNBU: CT-II 79554 oraz CT-II 80876. 
kiedy po zastoju spowodowanym III wojną północną zaczął się okres nasilenia pracy wydawniczej kolegium lwowskiego, sprowadzono nowe czcionki i zakupiono nowe narzędzia pracy. Prawdopodobnie S. Brzeżański skorygował i podpisał w taki sposób cały nakład tej edycji albo przynajmniej jego większość, ponieważ podobne zapisy znajdują się też na zachowanych egzemplarzach z BJ, Biblioteki Uniwersyteckiej w Warszawie i Ossolineum we Wrocławiu ${ }^{3}$.

Pracę korektorską podjął też Tadeusz Juda Krusiński (1675-1757), znany orientalista, misjonarz zakonu jezuickiego, zbieracz diariuszów poselstw papieskich i monarchów chrześcijańskich do szacha perskiego oraz innych dokumentów dotyczących działalności misji katolickich w Persji. Jego tłumaczenie z perskiego Doniesienia o poselstwie tureckim do Persji Ahmeda Efendiego Dürriego (-1772) wyszło drukiem we Lwowie w 1733, 1734 pod różnymi tytułami ${ }^{4}$ oraz w 1740 pod kolejnym tytułem Prodromus Ad Tragicam vertentis belli Persici Historiam.... Powołując się na Jana Daniela Janockiego $^{5} \mathrm{~K}$. Estreicher przypuszczał, że była jeszcze jedna, późniejsza i rozszerzona edycja z ok. 1755 r. wydana pod tytułem Analecta ad tragicam belli Persici historiam ${ }^{6}$, jednak nie udało się odnaleźć jej śladów w żadnej z bibliotek. Mimo tego, w naszych zbiorach zachowały się dwa ciekawe egzemplarze ostatniego, potwierdzonego źródłowo wydania z 1740 r., świadczące o dalszej pracy Krusińskiego nad tekstem i przygotowywaniu przez niego nowej edycji. Na odwrocie karty tytułowej jednego z nich ${ }^{7}$ autor własnoręcznym wpisem zwraca się do czytelnika usprawiedliwiając liczne błędy typograficzne odległością Lwowa od Ostroga, gdzie wówczas przebywał pełniąc stanowisko zastępcy rektora i rządcy majątków kolegium jezuickiego:

Benevolo Lectori. Typi errores, qui in Prodromum et Historiam irrepsêre, nolim mihi imputet discretus. Lector, optime gnarus, non dari actionem in distans: Ostrogû duntaxat Leopolim. Quodsi, pro rei aequitate incurio Typographo imputare velit, per me licet; amabo! Et quidem ipsius vitio et palmari in curia multa folia iterato praelo subiici debuissent, scholia enim et marginales nota majori parte omissa et interdum integri Fere versus desiderantur,

\section{BJ St. Dr. 38807, BUW 4g.8.3.14, ZNiO XVIII-436-III.}

4 Egzemplarze $\mathrm{z}$ tych edycji zachowane w zbiorach Biblioteki Narodowej Ukrainy im. W.I. Wernadskiego w Kijowie (Національна бібліотека України імені В.I. Вернадського) analizuje I. Ciborowska-Rymarowicz, Orientalista Tadeusz Krusiński (1675-1757) i egzemplarze jego prac w bibliotekach klasztornych i prywatnych XVIII wieku, „Bibliotekarz Podlaski” 2015, R. 16, nr 1, s. 11-34.

J.D. Janocki, Lexicon derer itztlebenden Gelehrten in Polen. T. 2, Breßlau 1755, s. 184.

E. XX, 305.

7 Krusiński J., Prodromus Ad Tragicam Vertentis Belli Persici Historiam: Seu Relatio Turcico-Persicae Legationis ..., Secunda Impressio Correctior. [Acc.:] Tragica vertentis belli Persici Historia..., Leopoli: Typis Coll. Societatis Jesu, 1740, [20] k., 175 s., [1] k., 34 s., 529 s., [11] k.; $2^{\circ}$. Dedykacja dla Stanisława Wincententego Jabłonowskiego zamieszczona na karcie tytułowej przy słowie Prodromus. E. XX, 305, XV, 419; sygn. LNNBU: CT-IV 14585. 
cum praejudicio sensûs variati. His incommodis obviando submiseram Elenchum Erratorum. Sed cum etiamtur erroribus stateat, proinde ad privatum usum aliqua tantum calamo correxi nam ipsum originale. Aliquo plura et scitu digna scholia apud eundem deperdium Minores Typi errores. Discretus Lector facile advertet et corriget.

Na brzegach książki są liczne autorskie rękopiśmienne poprawki, marginalia i uzupełnienia, ponadto wklejono w odpowiednich miejscach cztery karty z przepisanym tekstem dokumentów z archiwum karmelitów bosych kongregacji włoskiej, dotyczących treści dzieła:

Sequens epistola tardius Aspahamo ex archivo Patrum Fratrum Carmelitarum discalceatorum Congregat. Italicae una cum Brevi Apostolico Clementis VIII. submissa via Peterburgensi Ao 1743. 25 Mai sub data 25 Septembris 1742 isthuc referenda. Sigismundus D. G. ex Poloniae [...] (1 k., między s. 149 i 150 pierwszej paginacji);

Etiam sequens epistola eadem via, qua prior Aspahamo simul cum Brevi Apostolico missa. Vladislaus D. G. Rex Poloniae [...]” (1 k., między s. 161 i 162 pierwszej paginacji);

Breve Apostolicum. Clementis VIII. Ad Regem Persarum. Tardius via Peterburgensi Aspahamô sub data 25. 7bris 1742 ab Illsmo Rndissimo Philippo Maria a S. Augustino Vicario Apostolico Episcopo Aspahamensi submissum ex Archivo Conventus PP. FF. Carmelitarum Discalceatorum Congreg. Italicae extractum. Clemens Papa VIII. [...]”' 2 k. spisane z obu stron tekstem, między s. 68 i 69 trzeciej paginacji).

W drugim egzemplarzu z tej edycji, niestety zdefektowanym (druk bez karty tytułowej i końca ${ }^{8}$ ), wzmiankowane teksty zostały wydrukowane na osobnych, nawet paginowanych kartach i wstawione w odpowiednie miejsca. Marginalia i uzupełnienia z poprzedniego egzemplarza, nieco zmienione i poszerzone, zostały starannie wpisane na wąskie paski papieru i naklejone na dole kart. Nie wiadomo, czy zachowały się inne, poprawione w taki sposób egzemplarze tego wydania - brakuje o tym informacji w bibliograficznych opracowaniach dzieł J.T. Krusińskiego ${ }^{9}$. Nasza biblioteka posiada dziewięć egzemplarzy omawianego tytułu, w tym i druki z rękopiśmiennymi dedykacjami autorskimi, lecz żaden z nich nie ma podobnych not marginalnych.

Innym przykładem autorskich, korektorskich marginaliów jest egzemplarz drugiej (i ostatniej) edycji Pacta conventa Augusti III Regis Poloniarum ${ }^{10}$ autorstwa gdańskiego historyka i prawnika Gotfryda Lengnicha (1689-1774), jednego z najpopularniejszych oświeceniowych uczonych z dziedziny polskiego prawodawstwa i historii. Oprócz poprawek błędów typograficznych,

Toż samo, sygn. LNNBU: CT-IV 14585/3 egz.

9 E. XX, 305. Zob. też I. Ciborowska-Rymarowicz, dz. cyt.; I.O. Ціборовська-Римарович, Сходознавець Тадей Крусинський і його праиі у фондах Національної бібліотеки Украйни імені В. І. Вернадського, „Київські Полоністичні Студіі” 2003, t. 4, s. 123-148.

10 G. Lengnich, Pacta conventa Augusti III Regis Poloniarum Magni Ducis Lituaniae. Editio altera priore auctior et emendatior, Dantisci et Lipsiae: apud D. L. Wedel, 1763, [4] k., 206 s., [5] k ; 4 . E. XXI, 171; BN.XVIII.2.2223; VD18 14611147-001; sygn. LNNBU: CT-III 8494. 
zamieszczonych w wydrukowanej erracie przy końcu książki, autor naniósł dodatkowe własnoręczne poprawki na 72 stronach druku. Informuje o tym zapis na czystej karcie na początku książki, podpisany przez synowca autora, bibliografa i kolekcjonera Karola Beniamina Lengnicha (1743-1795): „Exemplum hoc b. Auctoris, manu ipsius emendatum est, atque a multis erratis typographicis, summa cura liberatum, quae in fine libri non sunt notata. C.B. Lengnich". Prawdopodobnie odziedziczył on tę książkę razem z całą biblioteką stryja i opatrzył ją jednym ze swoich ekslibrisów ${ }^{11}$.

Unikatowe znaczenie dla badaczy spuścizny jednego z głównych przedstawicieli polskiego oświecenia, biskupa warmińskiego Ignacego Krasickiego (1735-1801), ma przechowywany w naszej bibliotece tomik Listów i Pism Różnych..., wydrukowany w Warszawie u Michała Grölla w 1786 r. ${ }^{12}$ Edycja składa się z listów na różne tematy, pisanych prozą, niekiedy z dołączonymi do nich wierszami, oraz zawiera kilka listów poetyckich. Część tych pism stanowi fragmenty większych całości; spora liczba zawiera w nagłówku kryptonimy, a ich cechą wspólną jest brak datowania. Na czystej karcie na początku książki znajduje się zapis Jana Krasickiego (1763-1830), synowca poety, posiadacza bogatych kolekcji i pamiątek po wybitnym stryju: „Wszystkie w tych dwoch tomikach - znaki, kreski, litery, krzyze są ręką Stryia mego X.B.W. [= Xięcia Biskupa Warmińskiego] odznaczone. - Jan Krasicki. R. 1800".

Fakt występowania w tej książce autorskich marginaliów, oznaczenie ręką I. Krasickiego listów i wierszy krzyżykami lub kreskami, jest tym ważniejszy, że toczy się dyskusja na temat legalności samej edycji. Opierając się na fragmentach listów poety do wydawcy Franciszka Ksawerego Dmochowskiego (1762-1808), powstałych w okresie prac przygotowawczych do zbiorowej edycji pism autora Monachomachii ${ }^{13}$, niektórzy badacze przypuszczali, że dwutomowa gröllowska publikacja została wytłoczona bez zgody i współpracy autora, a tym samym znalazły się w niej teksty nieautoryzowane ${ }^{14}$. Jeśli zaufać zapisowi synowca biskupa i uznać marginalia w tym egzemplarzu za autentyczne, to jest naniesione ręką I. Krasickiego, można wysnuć odwrotny wniosek - autor opracowywał umieszczone w tym wydaniu teksty i przygotowywał do zbiorowej edycji.

11 W. Wittyg, Ex-libris 'y bibliotek polskich. XVI-XX wieku, Warszawa 1903, s. 42.

12 [I. Krasicki], Listy i Pisma Róźne X.B.W. T. 1, w Warszawie: Nakładem i Drukiem Michała Grölla, 1786, 195 s., [1] s., [2] k. ; 8. E. XX, 222; sygn. LNNBU: CT-I 9279/2 ex.

13 Krasicki, jak wiadomo, na prośbę Dmochowskiego przystąpił pod koniec życia do zbiorowej edycji swoich dzieł i przygotował do niej rękopisy. Rozpoczęcia druku nie dożył; wydanie Dmochowskiego było już edycją pośmiertną.

14 Por. R. Sobol, «Korespondencja Ignacego Krasickiego», z papierów Ludwika Bernackiego wydali i opracowali Zbigniew Goliński, Mieczysław Klimowicz, Roman Wołoszyński, pod redakcja Tadeusza Mikulskiego... [recenzja], „Pamiętnik Literacki” 1960, t. 51, z. 4, s. 481-495. 
Drugi typ autografów autorskich, znacznie liczniejszy i nie mniej cenny, to rękopiśmienne dedykacje twórców. Zainteresowanie tego rodzaju wpisami $\mathrm{i}$ ich rejestracją widoczne jest już od XIX w. w bibliograficznych pracach Teodora Wierzbowskiego i K. Estreichera ${ }^{15}$. Szeroko zakrojone, systematyczne ogłaszanie drukiem autorskich dedykacji z XVI w. przez Kazimierza Piekarskiego w okresie międzywojennym ${ }^{16}$ znalazło kontynuację w publikacji rejestrów rękopiśmiennych dedykacji ze zbiorów starych druków Biblioteki $\mathrm{ZNiO}$ we Wrocławiu ${ }^{17}$ oraz BN w Warszawie ${ }^{18}$.

Część dedykacji XVI-wiecznych, znajdujących się w załączonym do niniejszego artykułu wykazie autorskich rękopiśmiennych dedykacji z XVI-XVIII w. ze zbiorów LNNBU (poz. 17, 23, 24, 37, 40, 63), była już wcześniej opublikowana przez Rudolfa Kotulę ${ }^{19}$. Ich ponowna prezentacja spowodowana jest licznymi błędami w opisach Kotuli, o czym krytycznie pisał już K. Piekarski w swojej surowej recenzji ${ }^{20}$, oraz powojennym rozproszeniem kolekcji Wiktora Baworowskiego. Dwie pozycje wykazu (17 i 54) zostały powtórzone za K. Piekarskim ${ }^{21}$.

Ogółem zarejestrowano w wykazie LNNBU 67 polskich (w szerokim znaczeniu tego pojęcia) autorskich dedykacji, z których dziewięć pochodzi z XVI, 22 - z XVII, 36 - z XVIII w. Dominująca ich większość napisana została łaciną, jednak w wieku XVIII pojawiają się już wpisy w języku polskim, a nawet w modnym w owych czasach francuskim (poz. 52, 57). Wśród autorów i adresatów dedykacji znajdują się wybitne osobistości: Erazm z Rotterdamu ${ }^{22}$, Herkules Saxonia (Ercole Sassonia), Marcin Glicjusz z Pilzna, Andrzej Wolan, Daniel Mikołajewski. Niektóre dedykacje, skierowane do

15 T. Wierzbowski, Bibliographia Polonica XV ac XVI ss. Vol. 1-3, Varsovia 1889-1894; K. Estreicher, Bibliografia polska. T. 1-34, Kraków 1870-1951.

16 K. Piekarski, Dedykacje autorskie w zbiorze druków XVI wieku Biblioteki Kórnickiej, „Silva Rerum” 1927, t. 3, z. 11-12, s. 188-190; tenże, Rękopiśmienne dedykacje autorskie XVI wieku, „Przegląd Biblioteczny” 1929, R. 3, z. 2, s. 173-190.

17 J.A. Kosiński, J. Szczepaniec, Rękopiśmienne dedykacje autorskie XVI-XVIII wieku w zbiorach starych druków Biblioteki Ossolineum, „Ze Skarbca Kultury” 1964, nr 16, s. 187-213.

18 B. Sajna, M. Zychowiczowa, Rękopiśmienne dedykacje autorskie w zbiorze poloników XVI wieku w Bibliotece Narodowej, [w:] Studia ofiarowane profesor Alodii Kaweckiej-Gryczowej w 85-lecie urodzin. [T.] 1, [kom. red. P. Buchwald-Pelcowa i in.], Warszawa 1991, s. 63-76.

19 R. Kotula, Właściciele rękopisów i starodruków zbiorów wielkopolskich Z. Czarneckiego mieszczacych się obecnie w «Baworovianum» we Lwowie, Lwów 1929.

20 K. Piekarski, Rudolf Kotula: Właściciele rękopisów i starodruków zbiorów wielkopolskich Z. Czarneckiego, mieszczacych się obecnie w «Baworovianum» we Lwowie [recenzja], „Przegląd Biblioteczny" 1929, R. 3, z. 3, s. 388-415.

${ }_{21} \quad$ K. Piekarski, Rękopiśmienne dedykacje...

22 Ostatnio znalezionej książce z dedykacjami słynnego humanisty został poświęcony osobny artykuł, zob.: I. Kachur, Z historii bibliotek renesansowych - dar Erazma z Rotterdamu dla arcybiskupa Jana Łaskiego, [w:] Książka dawna i jej właściciele. Zbiór studiów. T. 2, pod red. D. Sidorowicz-Mulak, A. Franczyk-Cegły, Wrocław 2017, s. 17-32. 
bliskiego odbiorcy, mieszczą aluzje i zwroty zrozumiałe tylko dla adresata. Nie zawsze podpisane pełnym imieniem i nazwiskiem, zachowują anonimowość adresata w specjalnie ułożonym wierszu. Właśnie taką formę dedykacji preferował bazylianin Augustyn Sławiński (1746-po 1811), profesor matematyki i filozofii w Zamościu (poz. 44, 45).

Warto zaznaczyć, że w trakcie wyszukiwania dedykacji trafiają się zapiski wyglądające na pierwszy rzut oka jak autorskie, a w rzeczywistości sporządzone przez właścicieli w celu odnotowania pochlebnego dla siebie faktu znajomości z pisarzem ${ }^{23}$. Prawdopodobnie, przykładem takiej ,pseudo-dedykacji” jest dziwny wpis na egzemplarzu wydrukowanych w Bazylei w 1532 r. dzieł Platona w thumaczeniu i z komentarzami włoskiego renesansowego humanisty, założyciela i kierownika Akademii Platońskiej we Florencji Marsilio Ficino (1433-1499) ${ }^{24}$. Miał on poświadczyć podarunek książki ,wielce dostojnemu” staroście dybowskiemu, kasztelanowi oświęcimskiemu Wojciechowi z Padniewa Padniewskiemu (zm. 1610), uczyniony przez „najżyczliwszego sługę” Marsiliusa Ficinusa: „Magnifico Alberto Padniewski de Padniewo Castellano Oswięcijmen[sis] Dibovien [sis] Capitaneo in Pilca, Szaniec ūū Heredi. D[omi]no D[omi]no ac Patrono suo clemen[tissi]mo Marsilius Ficinus servus faventiss[im]us offert". Fałszywość tej dedykacji jest ewidentną i nie pozostawia wątpliwości - M. Ficino zmarł w 1499 r., na długo przed drukiem książki oraz urodzeniem się W. Padniewskiego. Bezspornym argumentem jest też wykorzystanie polskich liter (Oswięcijmen[sis]), zapewne nieznanych włoskiemu uczonemu.

Schemat opisów dedykacji ze zbiorów LNNBU zawartych w załączonym poniżej wykazie powiela $\mathrm{w}$ całości strukturę stosowaną przez poprzednich badaczy - K. Piekarskiego, Adama Józefa Kosińskiego i Józefa Szczepańca, Bożenę Sajnę i Marię Zychowiczową - jednak w nieco poszerzonym zakresie. Skróty w tekstach dedykacji i innych proweniencjach zostały rozwiązane, gdy było to możliwe. Pominięte przez autorów nazwiska adresatów, które udało się zidentyfikować, podane są w nawiasie kwadratowym. Ze względu na dodatkową wartość informacyjną opisów odnośnie darowizn oraz dalszych losów egzemplarzy, uzupełniono je podaniem innych znaków proweniencyjnych. Te wiadomości są też ważne dla ustalenia z jakiego historycznego, przedwojennego księgozbioru pochodzi dany egzemplarz. W dodatku do wykazu zgrupowano noty właścicieli dzieł informujące, że owe zostały im ofiarowane przez autorów (poz. 56-67). Wykaz dedykacji został także zaopatrzony w indeks alfabetyczny ich adresatów oraz indeks proweniencji. Na końcu znajduje się wykaz numerów dedykacji uporządkowanych według wieków.

23 Por. B. Sajna, Zychowiczowa M., Rękopiśmienne dedykacje..., s. 63.

24 Plato, Omnia Divini Platonis Opera. Translatione Marsilii Ficini, Emendatione Et Ad Graecvm Codicem Collatione Simonis Grynaei Nunc recens summa diligentia repurgata, Basileae: In Officina Frobeniana, 1532; 2. VD16 P 3277; BNF; sygn. LNNBU: CT-IV 21052. 


\section{WYKAZ DEDYKACJI}

ARNOLD Mikołaj (1618-1680)

1. Nobilissimo et Praestantissimo viro Juveni [... imię i nazwisko wytarte] $\mathrm{D}$ [omi]no et amico suo venerando in synceritatis et amicitiae aeternae monumentum obtulit Nicolaus Arnoldus m[anu] p[ro]p[ria] Ecclesiastes Beetgumensis in Frisia Occidentali.

In. prow.: 1. J[... dalej wycięte] Betgum - rps; 2. Ex libris R[everendi] $\mathrm{P}$ [atris] Sylvestri Łaszczewski O[rdinis] S[ancti] Basilij M[agni] applicat[us] Monasterio Leopolien[si] S[ancti] Georgij M[agni] m[anu] p[ropria]; NB. Liber haereticus - rps; 3. Бібліотека ОО. Василиян у Львові - eksl.

Na: Makowski, Jan (1588-1644), Johannis Maccovii SS. Theol. Doct. \& Prof. Theologia Polemica Posthuma, Edita Opera \& studio Nicolai Arnoldi Poloni, Franekerae: Typis \& impensis Idzardi Alberti \& Johannis Arceri, 1646; $12^{\circ}$. - E. nie notuje; COPAC; GBV 185908810.

M. Arnold jest wydawcą dzieła.

Sygn. LNNBU: CT-I 101446

BEIER Adrian (1634-1712)

2. Viro Magnifico Domino Danieli Schradero Consulo ac Scholarchae meritissimo Patrono summae Venerando offert Author.

In. prow.: 1. Ex libris R[evere]ndi Josephi Radzikowski m[anu] p[ro]p[ria] - rps;

2. Gwalbert Pawlikowski - piecz.

Na: Harmonia Struvio-Grotio-Schnobeliana, Sive Celeberrimi Icti Dn. Joachimi Schnobelii ... Dissertationes XXV. ad Pandectas Perpetuis ad Syntagma Juris Civilis..., Gedani: Typis \& Sumptibus Davidis Friderici Rhetii, 1693; 4․ - VD 17 14:632235G.

Sygn. LNNBU: CT-II 7031

BIEŻANOWSKI Stanisław Józef (1628-1693)

3. Conventui Religiosorum PP[atrum] Praedicatorum Leopolien[sium] autor donavit et consecravit.

In. prow.: Biblioteka Księży Dominikanów Lwowskich - piecz.

Na: Delicice Octidvance Ex Suauissimo amoris Diuini Cantico Canticorvm..., Cracoviae: Typis Vniversitatis, [1684]; 4 . - E. XIII, 106; Ossol. XVII, 552. Sygn. LNNBU: CT-II 6782/3 egz. 
BUJDECKI Florian Sebastian (1702-1765)

4. Pro Bibliotheca Conventus Prevorscens[is] Adm[odum] RR[everendorum] PP[atrum] Regularis observantiae S. Francisci Author offert.

In. prow.: 3989 - $\mathrm{N}$ inw.; 4260 - $\mathrm{N}$ inw.

Na: Vitce Sanctorum \& Sanctarum Ordinis Canonicorum Regularium Sanctce Hierosolymitance Ecclesice..., Cracoviae: In Officina Dominici Siarkowski, $1743 ; 4^{\circ}$. - E. XIII, 437.

Sygn. LNNBU: CT-II 105818

CZERWIAKOWSKI Rafał Józef (1743-1816)

5. Do Biblioteki W[ielebnego] J[ego] M[ości] X[iędza] Bogucickiego Filozofij i S[więtej] Teologij Doktora Historij Koscielney w Szkole Gł[ównej] Koronney Professora Publicznego Zgromadzenia do Xiąg Elementarnych Towarzysza $-z$ uszanowaniem ofiaruie Autor $\mathrm{m}[\mathrm{anu}] \mathrm{p}$ [ro]p[ria].

In. prow.: Gwalbert Pawlikowski - piecz.

Na: Dyssertacya O Szlachetności, Potrzebie I Użytku Chirurgii W Pożyciu Ludzkiem..., W Krakowie: w Drukarni Szkoły Główney Koronney, [po $12 \mathrm{~V}$ 1791]; $4^{\circ} .-$ E. XIV, 571.

Sygn. LNNBU: CT-III 13232

DOMAGALSKI Józef (1653-1710)

6. Illustriss[imo] R[evere]ndissimo Abbati Olivensi etc. D[omi]no [... dalej wycięte, = Hacki Michał Antoni].

Na: Trybvnat Głowny Koronny W Diploidzie Sprawiedliwosci ... Na Solenney Wotywie Pryzwitany W Kosciele Piotrkowskim..., Calissii: Typis Collegij Soc. Iesv, [1695]; 2 . - E. XV, 276; Ossol. XVII, 1660.

Sygn. LNNBU: CT-IV 26231

7. $\mathrm{R}$ [everendo] $\mathrm{P}$ [at]ri in X[risto] $\mathrm{P}[$ at]ri Adamo Chodorski Soc[ietatis] Jesu Servus humill[imus] Aut[hor].

In. prow.: Collegij Luceorien[sis] Soc[ietatis] Jesu - rps.

Na: egz. dzieła wyżej wymienionego.

Sygn. LNNBU: CT-IV 104235

DUNIN Piotr Stanisław (1635-1704)

8. R[evere]ndo P[at]ri in Christo Patri Bernardo Żołkiewski Societatis Jesu Professo [... dalej wycięte].

In. prow.: Collegij Luceoriensis Soc[ietatis] Jesu pro Cubiculo P[atris] 
Concionatoris Anno D[omini] 1709 - rps.

Na: Kazanie na Pogrzebie ... Władysława Michała Skoroszewskiego Chorazego Poznanskiego..., W Warszawie: w Drukarni I. K. M. u Oycow Scholarum Piarum, [po 18 V 1695]; 2. - E. XXV, 408; Ossol. XVII, 1748.

Sygn. LNNBU: CT-IV 5987

ELISZ Aleksander ( -1707).

9. R[evere]ndo in Christo Patri Patri Valentino Queck Praeposito Provinciali Societatis Jesu Prov[inciae] Poloniae Patri Dignissimo Filius Indignissus off[ert] A[uthor].

Na: Gory Vkoronowane Ieymsc Pannę Zofia Engracia Hvlewiczowne Sędziankę Evcka na Wesele Niebieskie Wynoszace ... Pogrzebowym Kazaniem Ogloszone w Kośćiele Łuckim Societatis Iesv..., We Lwowie: W Drukarni Collegium Societatis Iesv, [1698]; 2 . - E. XVI, 48; Ossol. XVII, 1852.

Sygn. LNNBU: CT-IV 6005

10. Reverendo in Christo Patri Patri Francisco Siewierski Inter Superiorum Choros Seraphino Memor affectuum gratiarum ipsaq[ue] nunc memoria[m] dolorosissimus Patri suo faventissimo offert super amantissimo servus filius A[uthor].

Na: egz. dzieła wyżej wymienionego.

Sygn. LNNBU: CT-IV 6006

ERASMUS Roterodamus Desiderius (1469-1536)

11. R[everendissi]mo D[omino] Archie[pisco]po Polonie Erasmus Rot[erodamus] Dono misit.

In. prow.: 1. Ioannis a Lasco Poloni \& amicor[um] - rps; 2. Nēphe kai apistei - rps ręką J. Łaskiego mł.; 3. I L 1527 / Ioannis de Lasco - supereksl. herb.; 4. eksl. [?] Jana Laskiego ml. w postaci dwóch drzeworytowych medalionów: z herbem Łaskich Korab i dewizą: „In portV navigo” i drugim na verso k. tyt. $\mathrm{z}$ portretem Erazma i napisem w otoku: „ERASMVS ROTERODAM[US]"; 5. Ex hui[us] bybliotheca emit Georg [... dalej wytarte] - rps; 6. Monasterii O. S. Basilii M[agni] Leopoli[ensis] / 1824-1526 = 298 - rps; 7. Центральна Василіянська бібліотека у Львові - piecz. łacińskie marg., uwagi i adnotacje, m.in. ręką Jana Łaskiego mł.

Na: Irenaeus, episcopus Lugdunensis (ok. 140 - ok. 200), Opvs ervditissimvm Divi Irenaei Episcopi Lvdvnensis; in qvinque libros digestum...., [Basileae: Apud Ioan[nem] Frob[enium], VIII], 1526; $2^{\circ}$. - Adams I 150; BJ16 I 271; VD 16 I 316. Erazm z Rotterdamu jest komentatorem i wydawcą dzieła. 
Adresatem dedykacji jest Jan Łaski st. (1455-1531), arcybiskup gnieźnieński i prymas Polski.

Współopr. z poz. 12.

Sygn. LNNBU: CT-IV 21191/adl.1

12. Ornatiss[imo] Barono Jaroslao a Lasko palatino Siradiens[is] etc. Eras[mus] Rot[erodamus] dono misit.

In. prow.: 1. Ioannis a Lasco Poloni \& amicor[um] - rps; 2. Nēphe kai apistei - rps ręką J. Laskiego mł.; 3. Центральна Василіянська бібліотека у Львові - piecz. Zob. też prow. poz. 11.

Na: Erasmus, Roterodamus (1467-1536), Christiani matrimonii institutio..., Basileae: apud Ioannem Frobenium, 1526; 2. - Adams E 518; VD 16 E 2183. Adresatem dedykacji jest Hieronim Łaski (1496-1541), polski polityk i dyplomata, synowiec prymasa J. Łaskiego, brat J. Łaskiego mł.

Współopr. z poz. 11.

Sygn. LNNBU: CT-IV 21191/adl.2

GŁOWCZYŃSKI Stanisław (1663-1722)

13. I[e]g[o Moś]ci Panu Danielowi Burgoltowi M[ości] M[oś]ci Panu i Dobrod[ziejowi] Autor pracę swoią offiar[uje].

In. prow.: Gwalbert Pawlikowski - piecz.

Na: S. Judasz Thadaeusz Apostot Patron w Polszcze..., W Kaliszu: w Drukarni Kollegium Soc. Jesu, 1713; 2 . - E. XVII, 191.

Sygn. LNNBU: CT-IV 13806

GRABOWSKI Ignacy (1727-1810)

14. Pro Bibliotheca Cracoviensi P[atrum] Ordi Discalceatorum S[anctis]s[i] mae Trinitatis R[edemptionis] Capt[ivorum] applicat, qui compillavit F[rater] Jgnatius a S[anctae] Maria de Mercede Ejusdem Ordi m[anu] p[ro]pria.

In. prow.: 1. Ex applicat[ione] Ecclesiae Lopat[inensi] Nro 57 - rps; 2. Музей А. С. Петрушевича - piecz.

Na: Prawa Powszechne Przeciw drukowanemu Roku 1766. Wyktadowi Praw Dyssydentskich ... Podane..., [Lwów: drukarnia Bractwa Św. Trójcy, 1767]; $8^{\circ}$. - E. XXV, 218.

Sygn. LNNBU: CT-I 9890/3 egz.

HAEN Anton van (1704-1776)

15. Discipulo suo [Kneè Józef] offert Auctor m[anu] p[ro]p[r]ia. 
In. prow.: 1. Kneè $\mathrm{m}[\mathrm{anu}] \mathrm{p}[\mathrm{ro}] \mathrm{p}[\mathrm{r}] \mathrm{ia}-\mathrm{rps}$; 2. Krausneker - piecz.; 3. Instytut Ossolińskiego - piecz.

Na: Ratio Medendi, In Nosocomio Practico... [P. 15], Vindobonae: Typis Iohannis Thomae Trattner, 1773; $8^{\circ}$. - ONB.

Sygn. LNNBU: CT-II 45801

HEINTZ Franciszek (1668-1729)

16. R[evere]ndo Patri Stanislai Kaznowski. Humillimus servus author [imię i nazwisko adresata starannie zakreślone].

In. prow.: Luceoriensis Collegii S[ocietatis] J[esu] 1722 - rps.

Na: Zazdrosny Nieba z Ziemia O Herbowne a Szacowne ... Piotra Hrabi na Przebendowie Przebendowskiego..., [b. m.: bw, 1711]; $2^{\circ}$. - E. XVIII, 83.

Sygn. LNNBU: CT- IV 26204

HERBEST Stanisław (Neapolitanus, XVI w.)

17. Al[berto] Basseo Scebresen[si] amico suo autor mittit.

In. prow.: Biblioteka Fundacyi W. Hr. Baworowskiego - piecz.

Na: De Pretiosissima Christi Passione Elegia..., VVratislaviæ: [Kryspin Scharffenberg], 1564; 4․ - E. XVIII, 125; Kotula 287 (błędnie podaje adresata ded. jak Haase M.); Piekarski, ded. XVI, 37; Piekarski, rec. 398.

Sygn. LNNBU: CT-II 75978

KAŁUSKI Stanisław (1651-1711)

18. R[evere]ndo Patri in Christo Patri Francisco Siewierski [... dalej wycięte]. Na: Kazanie Na Swięto B. Iana Kantego Kanonika Krakowskiego..., Lvblini: Typis Collegij Societatis Jesv, [1694]; 2 . - E. XIX, 69; Ossol. XVII, 2994.

Sygn. LNNBU: CT-IV 26233

19. Jasnie Oswieconemu J[ego] M[ości] Panu Kasztelanowi Krakowskiemu Hetmano[wi] Wielkiemu Koronnemu J[ego] M[ości] Panu Dobrodzieiowi [= Stanisławowi Janu Jabłonowskiemu] Unizony Author.

Na: egz. dzieła wyżej wymienionego.

Sygn. LNNBU: CT-IV 104201

KLAGE Tomasz (ok. 1598-1664)

20. R[evere]ndo P[at]ri Praemislao Rudnicki Soc[ietatis] JESU ad S[anctum] Ioannem Author. 
In. prow.: Gwalbert Pawlikowski - piecz.

Na: Didymi Hermannovillani Disqvisitiones Vbiqvistica Sive De Christo

Contra Vbiqvistas..., Augustæ Gediminiæ: Typis Hetærianis [Wilno:

Drukarnia Akademicka], 1644; 8 . War. A. - E. XIX, 271; Ossol. XVII, 3098.

Sygn. LNNBU: CT-I 11180

KLAZOWSKI Mikołaj

21. R[everendo] P[atri] Alexandro Karczewski S[ocietatis] J[esu] Oratori ab omni Cathedra Dignissimo indignus author offert.

Na: Wiek Fortunny Easkami Ducha Nayświętszego..., We Lwowie: w Drukarni Coll. Soc. Jesu, 1749; $2^{\circ}$. - E. XIX, 273.

Sygn. LNNBU: CT-IV 104199

KLECZYŃSKI Józef (1675-1725)

22. Reverendo in $\mathrm{Ch}$ [ris]to P[at]ri Nicolao Naramowski Soc[ietatis] Jesu. Servus in $\mathrm{Ch}[$ risto] Author. Luceoriae.

Na: Prawda Jasnie Oswieconego Trybunatu Koronnego..., W Toruniu: Drukował Jan Nikolai, [1712]; $2^{\circ}$. - E. XIX, 276.

Sygn. LNNBU: CT-IV 26202

\section{KŁODZIŃSKI Maciej (1551-1616)}

23. Re[vere]ndo d[omi]no Martino Pilsne[n]s[i] S[anctae] Theologiae Doctori Cracoviens[i] Vratislaviensi Can[oni]co Autor conf[rat]ri suo obse[rvantissi] mo dedit in perpetui amoris pignus Crac[oviae].

In. prow.: 1. Biblioteka XX. Czartoryskich - piecz.; 2. Z duplikatów biblioteki X.X. Czartoryskich - piecz.; 3. Biblioteka Fundacyi W. Hr. Baworowskiego - piecz.

Na: Sirino, Girolamo (XVI w.), Liber De Modo Acqvirendae Divinae Gratiae..., Cracoviae: In Officina Typographica Lazari, 1583; 4 . - E. XXVIII, 115-116; BJ16 S 900; BJ Pol. 2276; Kotula 325 (błędnie podaje Hieronima Sirinusa jako autora dedyk., wówczas nieżyjącego); Ossol. XVI, 2286; Piekarski, rec. 405.

M. Kłodziński jest tłumaczem tego dzieła.

Sygn. LNNBU: CT-II 79435

\section{KRAIŃSKI Krzysztof (1556-1618)}

24. Reverendo Viro Domino Joanni ministro Zolinen[si] mittit amoris gr[ati] a Auctor. / Oddać w Lanczucie x: pastorowi. 
In. prow.: 1. Biblioteka X. J. Biergiela - piecz.; 2. Z Księgozbioru Zygmunta Czarneckiego - eksl.; 3. Biblioteka Fundacyi W. Hr. Baworowskiego - piecz. Na: Porzadek Nabożeństwa Kośćioła powszechnego Apostolskiego..., Drukowano w Toruniu [Kraków: Aleksy Rodecki], 1599; 4 . - E. XX, 208; Kotula 293; Ossol. XVI, 1336.

Sygn. LNNBU: CT-II 75750

KRUSIŃSKI Tadeusz Juda (1675-1757)

25. J[ego] M[oś]ci Panu Rochowi Jabłonowskiemu Podcz[aszemu] Halick[iemu] in arrham perpetuandi affectus Devotissimo Cultu Obtulit Author.

In. prow.: 1. Franciszek Jabłonowski - rps; 2. M. Meldon - rps; 3. Joannes de Januszowski 1817 m[anu] p[ropria] - rps; 4. Biblioteka Poturzycka J. W. D. [= Józefa i Włodzimierza Dzieduszyckich] - piecz.

Na: Prodromus Ad Historiam Revolutionis Persicae..., Leopoli: Typis Collegij Soc. Jesu, 1733; 4 . - E. XV, 419 (aut. - Durry Effendi, właśc. Ahmed Efendi Dürri).

Sygn. LNNBU: CT-II 95391

26. [Jos]epho Andrzeiewicz Praeposito Domus Professae Devotissimo Cultu Obtulit Author.

In. prow.: 1. Collegium Tarnopolitanum Soc[ietatis] Jesu - piecz.; 2. Collegium Soc[ietatis] Jesu Chyroviense - piecz.

Na: Prodromus Ad Tragicam vertentis belli Persici Historiam..., Leopoli: Typis Coll. Soc. Jesu, [po 20 VI] 1734; 4 . - E. XV, 419 (aut. - Durry Effendi, właśc. Ahmed Efendi Dürri), XX, 304-305.

Sygn. LNNBU: CT-II 81000

27. Perillustri M[agnifico] D[omino] D[omino] Joan Gierkowski [?] Sac[rae] Reg[iae] M[aie]s[ta]tis et Reip[ublicae] Pol[oniae] Colonello [... dalej wycięte].

In. prow.: 1. Z Biblioteki Gwalb: Pawlikowskiego - eksl.; 2. Gwalbert Pawlikowski - piecz.

Na: egz. dzieła wyżej wymienionego.

Sygn. LNNBU: CT-II 81000/2 egz.

28. Excellentissimo Ill[ustrissi]mo D[omino] D[omino] V[enceslao] Rzewuski Capitaneo Crusviciens[i] Notario Regni offert Devotissimo Patrono 
colend[issimo] [... dalej wycięte].

In. prow.: 1. N 76 Consig. - rps [Józef Dobek Dzierzkowski]; 2. Biblioteka Poturzycka J. W. D. [= Józefa i Włodzimierza Dzieduszyckich] - piecz.

Na: egz. dzieła wyżej wymienionego.

Sygn. LNNBU: CT-II 81000/3 egz.

29. $\mathrm{R}$ [everen]do P[at]ri in X[ris]to P[at]ri Antonio Dobrski Soc[ietatis] Jesu Rect[ori] Coll[egii] Lubl[inensi] devotissimo cultu obtulit Author.

In. prow.: Biblioteka Chrzanowskich Moroczyn - piecz.

Na: Tragica Vertentis belli Persici Historia ..., Leopoli: Typis Coll. Societatis Jesu, 1740; $2^{\circ}$. - E. XX, 305.

Sygn. LNNBU: CT-IV 50557/2 egz.

LESZCZYŃSKI Sebastian Jan (-1708)

30. Spectabili D[omi]no Sebastiano Kasprowicz Consuli Becen[si] D[omi] no et Patrono suo Autor D[e]d[itissim]o.

In. prow.: Gwalbert Pawlikowski - piecz.

Na: Gratia Crvcis Et Virginis Proles. B. Joannes A Crvce..., (Lesnae: Imprimebat Michael Buk, [po 20 X] 1675); $2^{\circ}$. War. A. - E. XXI, 214-215; Ossol. XVII, 3918.

Sygn. LNNBU: CT-IV 13742

MAMONICZ Ignacy (15..-16..)

31. In signu[m] amoris et benevolentiae Do[mi]no Ioanni Rolascio [?] Ignacius Mamonicz Dono mittit A. [inną ręką dopisano:] Author.

In. prow.: 1. Zygmunt Czarnecki - supereksl. herb.; 2. Biblioteka Fundacyi W. Hr. Baworowskiego - piecz.

Na: Aland, Jan (ok. 1559-1641), Pamiatka Jaśnie Oświeconemu ... Mikolaiowi Chrysztofowi Radziwilowi..., W Wilnie: W Drukarni Leona Mamonicza, [po 15 X 1617]; $4^{\circ}$. - E. XII, 93; Ossol. XVII, 79.

I. Mamonicz jest autorem wydrukowanej w tym dziele dedykacji dla Zygmunta Karola Radziwiłła.

Sygn. LNNBU: CT-II 87205

PLESZKIEWICZ (Pleskiewicz) Terapont (1715-1758)

32. R[everendissi]mo P[atri] Joanni Hieronymo Nerezius OSBM Rectori Collegii Buczacen[sis] Patrono Col[endissi]mo Offert devotissimus Servus [... dalej wycięte]. 
In. prow.: Центральний Василіянський архів і бібліотека. Львів I, Жовківська 36 - piecz.

Na: Kazanie Na Uroczystosc Zestania Ducha Przenayswiętszego Przy szczesśliwym Ingressie do Katedry swoiey ... Sylwestra Lubienieckiego Rudnickiego Exarchi Metropolii Kiiowskiey Halickiey y Całey Rusi, Biskupa Łuckiego y Ostrogskiego, w Roku Pańskim 1752 miane, Potym zaś Temuz ... Przy Dorocznych Imieninach S. Sylwestra Papierza w Roku Pańskim 1755 [!] dedykowane. Przez Pewnego Zakonnika Zakonu Swiętego Bazyliego Wielkiego, Prowincyi pod Tytułem Protekcyi Nayświętszey Maryi Panny, na ten Czas w Monasterze Poczaiowskim rezyduiacego, z Pozwoleniem Starszych, W Drukarni J.K. MCI Poczaiowskiey: u WW. OO. Bazylianow, 1754. w Miesiącu Grudniu, [13] k.; ${ }^{\circ}$. - E. nie notuje.

Autora dzieła ustalono na podstawie bazyliańskich szematyzmów i kryptogramu pod przedmową: X.T.P.Z.S.B.W. [= Xiądz Terapont Pleszkiewicz Zakonu Świętego Bazylego Wielkiego].

Sygn. LNNBU: CT-IV 50473

PONIŃSKI Franciszek (1661-1714)

33. Perill[ustr]i et Adm[o]d[u]m R[evere]ndo D[omi]no D[omi]no Joanni Jałowicki Surrogatori et Canonico [... dalej wycięte].

Na: Nowina Na Swiat Polski Głosna: Zycie Pobozne I Smierc ... P. Macieia z Brvdzewa Mielzynskiego Kasztelana Szrzemskiego..., W Poznaniv: w Drukarni I. K. M. Koleium [!] Societatis Iesv, [po 6 V 1697]; $2^{\circ}$. War. B. Por. E. XXV, 53-54; Ossol. XVII, 5659.

Sygn. LNNBU: CT-IV 5988

34. Ch[arissi]mo in X[ris]to Fr[atr]i M. Sebastiano Zacherla S[ocieitatis] $\mathrm{J}[\mathrm{esu}]$ [... dalej wycięte].

Na: egz. dzieła wyżej wymienionego.

Sygn. LNNBU: CT-IV 6002

35. Reverendo Patri in Christo Patri Josepho Olechowicz [... dalej wycięte]. Na: Smierc Kaznodzieia Przy Załosney Depozycyi ... P. Andrzeia z Pogorzeli Bvtakowskiego..., W Poznaniu: w Drukarni Koleium [!] Societatis Iesv, [po 23 II 1699]; 2․ - E. XXV, 54; Ossol. XVII, 5661.

Sygn. LNNBU: CT-IV 6003 
POSZAKOWSKI Jan Antoni (1684-1757)

36. R[everendo] P[atri] Josepho Jankowski Soc[ietatis] Jesu offert an[nno] 1750 Auctor $\mathrm{m}$ [anu] $\mathrm{p}$ [ropria].

In. prow.: 1. Ex libris E. A. R. P. Fr[atr]is Alberti Słotwiński S[acrae] $\mathrm{T}$ [heologiae] M[agistri] Exprov[incialis] - rps; 2. Ex libris Tomasz Drozdowicz S[ocietatis] Jesu - rps; 3. Inscriptus Catalogo Bibl[iothecae] Collegii NeoSandec[ensis] Soc[ietatis] Jesu - rps; 4. Bibliotheca Coll[egii] Soc[ietatis] Jesu Staraviesiae - piecz.; 5. Ex libris Collegii Chyroviensis Societatis Iesu [poniżej ręcznie :] A Coll[egio] Vilnensi S[ocietatis J[esu] 1828 - eksl.

Na: Historyi Kalwinskiey Częsc Trzecia ..., W Warszawie: w Drukarni J. K. Mci y Rzeczypospolitey, Collegii Societatis Jesu, 1749; 4. - E. XXV, 120.

Sygn. LNNBU: CT-II 79534/2 egz.

PUDŁOWSKI Melchior (ok. 1539-1588)

37. Pro g[e]n[er]oso d[omi]no St[anisla]o Prosinski [?] d[omi]no et amico meo [... dalej wycięte].

In. prow.: 1. Zygmunt Czarnecki - supereksl. herb.; 2. Biblioteka Fundacyi W. Hr. Baworowskiego - piecz.

Na: Elegia ob mortem ... D. Ioannis Comitis de Tarnow, Castellani Cracovien[sis] exercitvvm Regni Poloniae imperatoris..., [Kraków]: Lazarvs Andreae excudebat, [1561]; 4. - E. XXV, 399; Kotula 479; Piekarski, rec. 401.

Sygn. LNNBU: CT-II 76369

REICHHELM Sigismund Siegfried (1613-1678)

38. Clarissimo atq[ue] Eximiè D[omino] D[omi]no Johanni Crull[...?] I[uris] $\mathrm{C}$ [onsultor] dignis[simo] Amico Fautori conreoq[ue] suo honoratissimo, cum [...] ad opponendum meum offert R. [= Reichhelm, prawa część zapisu wycięta]. Na: Disputatio Juridica De Adjecto..., Jenæ: Prelo Lobensteiniano, 1638; 4 . - ICCU.

Sygn. LNNBU: CT-II 30997

SASSONIA Ercole (Saxonia Hercules, 1551-1607)

39. Ill[ustrissi]mo D[omino] D[omino] Sigismu[n]do Baroni a Wolckhanstein et Roddenneck $\mathrm{D}$ [omino] et patrono cel[sissi]mo auctor $\mathrm{D}$ [ono] $\mathrm{D}$ [edit].

In. prow.: Gwalbert Pawlikowski - piecz.

Na: De Plica Qvam Poloni Gwoździec, Roxolani Koltvnvm Vocant, Pat[avii]: Apud Laure[n]tiu[m] Pasquatu[m], [po 22 IV] 1600; 4. War. A. - Adams S 534; BJ16 S 304; BJ Pol. 2175; E. XXVII, 171-172; Ossol. XVI hist., 2657; W 690.

Sygn. LNNBU: CT-II 6949 
40. D[omino] Stanislao Curelowie[nsi] ab autore pro[latum] G[eneroso] $\mathrm{P}$ [atri] Brzechwa d[ono] d[atum]. 16002 Septe[m]b[ris].

In. prow.: 1. Biblioteka Fundacyi W. Hr. Baworowskiego - piecz.

Na: egz. dzieła wyżej wymienionego. - Kotula 432.

Sygn. LNNBU: CT-II 80027

SCZANIECKI STEFAN (1655-1736)

41. Collegio ad B[eatam] V[irginem] M[ariam] Jaros1[aviensi] Soc[ietatis] Jesu 1722. Author $\mathrm{m}$ [anu] $\mathrm{p}$ [ropria].

In. prow.: 1. Ta Xiązka iest Authora X. Teofila Rutki S[ocietatis] J[esu] Ktorą On napisał przeciw Dyssydentom, to iest przeciw Lutróm y Kalwinóm. Z Ktorej Czytelnik wiele się może nauczyć iak potrzeba Artykuły Wiary Katolickiey przeciw Dyssydentom bronić - rps na wyklejce; 2. Бібліотека ОО. Василиян у Львові-eksl. Na: Sczera Prawda Przeciw Obłudnemu Fatszowi, To iest: Prosta z Pisma Swiętego, Odpowiedz Katolicka; na wykrętne, osobliwie Karola Drelinkurta, z tegoż Pisma Zarzuty Dyssydentskie, W Poznaniu: W Drukarni Kolleg. Soc. Jesu, 1719; $4^{\circ}$. - E. XXVII, 324.

Sygn. LNNBU: CT-II 111177

SIENKIEWICZ Antoni Marcin (1690-1752)

42. Ad[modu]m R[evere]ndo Patri Rectori Varsaviensi [podpis węzłowy:] BAP [= Bernardus a S. Antonio Patavinus - imię zakonne A. Sienkiewicza] $\mathrm{m}[\mathrm{anu}] \mathrm{p}[\mathrm{ro}] \mathrm{p}[$ ria $]$.

In. prow.: 1. Zygmunt Czarnecki - supereksl.; 2. Biblioteka Fundacyi W. Hr. Baworowskiego - piecz.

Na: Consistorium Honoris Infvlati In Purpurata Hosiorvum Domo Super Basim Gentilitiae Plante Fvndatvm ..., [b. m: b.w.], 1719; 2 . - Bibl. Kórnicka (nie wymienia autora); E. XVIII, 295 (na: Hosius Stanisław Józef); XXVIII, 40 (przypis: „Autorstwo Sienkiewicza jest wielce prawdopodobne”).

Sygn. LNNBU: CT-IV 50910

SŁAWIŃSKI Augustyn (1746 - po 1811)

43. Offert ipse humilis author hunc libellum suum Bibliothecae Buczaczensi Basilian[orum] Anno 1784 anno [sic] die 9 Januarii V[ester] S[ervitor]. In. prow.: 1. Bibliothecae Scholarum Buczaczensium comparatus $1784 \mathrm{~A}[\mathrm{nn}]$ o - rps; 2. Бібліотека ОО. Василіян у Крехові - piecz, eksl.

Na: Institutiones Arithmeticae..., Zamoscii: Typis Academicis, 1782; $8^{\circ}$. COPAC; E. XXVIII, 227. 
44. Mężu Wielki przyim małą daninę odemnie, Niech twe łaski dane mi nie padą daremnie, Niech więc Lewiński w szczęsciu lat tyle rachuje, Jle się liczb /:tak życzę:/ w tey książce znayduje. Na: egz. dzieła wyżej wymienionego.

Sygn. LNNBU: CT-I 78653/3 egz.

45. Którego serce kocha, temu ręce daią.

Czy co z swey pracy, czy też co własnego maią.

Owoż Teologii Przezacny Doktorze!

Przyim coć daie Filozof w powinney pokorze.

In. prow.: 1. Hic Liber est meus, Testis est Deus. Quis illum quaerit, hoc nomen erit. Adamus natus, Wiszniewski vocatus - rps; 2. Biblioteka Chrzanowskich Moroczyn - piecz.

Na: egz. dzieła wyżej wymienionego.

Sygn. LNNBU: CT-I 78653/2 egz.

SOOS Michael Balog (XVIII w.)

46. Viro Excellentissimo, ac longe longeque per omnem Orbem Exuditorum, Solis ad instar, Clarissimo, Celeberrimo, Illustrissimo Domino L[ibero] $\mathrm{B}$ [arono] Gerhardo van Swieten Utriusque S[acrae] C[aesareae] R[egiae] [et] A[postolicae] Maiestatis Archiatro Archiatrorum Summo Magni Boerhavii Commentatori Immortali, /:tit. tit. tit. tit.:/ Domino ac Fautori suo ingiter colendissimo, mente offert submississimo Auctor. m[anu] p[ro]p[ri]a.

In. prow.: 1. Ex libris Georg[ii] Chmel Silesii Teschinensis Med[icinae] Stud[iosi] - rps; 2. W.O. 6455 - rps [Wronowski, Ossolineum]; 3. 36985 rps [nr inw. biblioteki Ossolineum].

Na: Dissertatio Inavgvralis Physiologico-Anatomica exhibens OsteogeniamHvmanam..., Trajecti Ad Rhenvm: Ex officina Ioannis Broedelet, 1766; $4^{\circ}$. - BNF; COPAC.

Sygn. LNNBU: CT-II 57879

ŚWIRSKI Kazimierz Tomasz Salawa (1688-1750)

47. J[esus] M[aria] J[oseph]. L[audetur] I[esus] C[hristus]. A Monseigneur le Comte de Unichow Ustrzycki Castell[ano] a Przemysl Auctor z usługami swoiemi ofiaruie X[iądz] Swirski Ca[nonicus] M[etropolitanus] L[eopoliensis] Sch[olasticus] C[athedrarius] Ch[elmensis] D[rohobycensis] Z[ienkoviensis] $\mathrm{P}$ [raepositus] $\mathrm{m}$ [anu] $\mathrm{p}$ [ropria].

In. prow.: 1. Ex Bibliotheca Con[ventus] Dobrom[iliensis] OSBM - rps; 
2. Bibliotheca Dobromilensis Ord[inis] S[ancti] Basilii M[agni] - piecz.; 3. Бібліотека ОО. Василіян у Крехові - piecz., eksl.

Na: Honor Laureis Poeticis Coronatus, Senatus Spiritualis Cultu Poetico Adoratus ..., Lublini: Typis S. R. M. Coll. Soc. Jesu, 1749; 8 . - E. XXX, 105.

Sygn. LNNBU: CT-I 44686

48. J[esus] M[aria] J[oseph]. L[audetur] I[esus] C[hristus]. Pro Coll[egio] Jaroslaviens[i] ad B[eatam] V[irginem] M[ariam] Thaumaturgam Dolorosam Auctor cum debitis suis obsequis offert. C[asimirus] de Rom[anow] Swirski J[udicis] T[ribunalis] D[eputatus] C[anonicus] M[etropolitanus] L[eopoliensis] Sch[olasticus] Ch[elmensis] D[rohobycensis] Z[ienkoviensis] $\mathrm{P}$ [raepositus].

In. prow.: Бібліотека ОО. Василиян у Львові - eksl.

Na: egz. dzieła wyżej wymienionego.

Sygn. LNNBU: CT-I 86105

TRUBLET Nicolas-Charles-Joseph (1697-1770)

49. Pour Monsieur Le Baron de *** Schmerling de la part de son très humble et très obeissant serviteur Trublet.

In. prow.: 1. Stanisław Wronowski-zapis pojedynczymi literami na kolejnych kartach; 2. SW [= Stanisław Wronowski] - piecz.; 3. WO 6260 / Dar Wron. spis franc. - rps [Wronowski, Ossolineum]; 4. 38160 - rps [nr inw. biblioteki Ossolineum].

Na: Essais Sur Divers Sujets De Litterature Et De Morale..., A Paris: Chez Briasson..., 1737; $12^{\circ}$. - BNF; COPAC.

Sygn. LNNBU: CT-II 57280

TRZCIŃSKI Andrzej Jan Kanty (1749-1823)

50. Jaśnie Wielmożnemu I[ego] m[oś]ci Panu Potockiemu Marszałkowi Nadw[ornemu] W[ielkiego] X[ięstwa] Litew[skiego] Kawalerowi Orderów $\mathrm{O}$ [rła] B[iałego] i S[więtego] S[tanisława] Komissarzowi w Przesw[iatłej] Kom[isji] Eduk[acji] \&c. Autor ofiaruie.

In. prow.: Biblioteka Poturzycka J. W. D. [= Józefa i Włodzimierza Dzieduszyckich] - piecz.

Na: Dyssertacya O Wzroście Nauk Wyzwolonych i Mechanicznych..., W Krakowie: W Drukarni Jgnacego Grebla..., 1787; 4 . - E. XXXI, 348.

Sygn. LNNBU: CT-II 95409 
51. Wielmożnemu J[ego] M[oś]ci Panu Badyniemu [!] Szambelanowi J[ego] $\mathrm{K}$ [rólewskiej] M[oś]ci Autor ofiaruie.

In. prow.: Книгозбірня „Студіону” у Львові - piecz.

Na: egz. dzieła wyżej wymienionego.

Sygn. LNNBU: CT-II 94990

52. A Monsieur l'abbé Koncewicz Prefet des R[évérends] P[ères] Basiliens de la part de l'auteur.

Na: Dyssertacya O Wzroście Świateł..., W Krakowie: w Drukarni Szkoły Główney Koronney, 1791; 4 . - E. XXXI, 347.

Sygn. LNNBU: CT-II 95116

WIECZORKOWSKI Michał Ignacy (1673-1750)

53. R[evere]ndo Patri Joanni Małżycki Soc[ietatis] Jesu Markovecensi missionario offert Author.

In. prow.: 1. Maryanna Gorayska Z S B [= Zakonnica Swiętego Benedykta] - rps; 2. nalepka na grzbiecie biblioteki benedyktynek lwowskich.

Na: Segneri, Paolo (1624-1694), Manna Duszy Albo Cwiczenia się Duchowne ... z Wtoskiego Języka na Polski Przettumaczone..., W Sandomierzu: w Drukarni J.K.M. Col. Soc. Jesu, 1732; 4 . - E. XXVII, 345, XXXII, 448; Gwioździk 29n.

Wieczorkowski jest tłumaczem tego dzieła.

Sygn. LNNBU: CT-II 104521/2/3 egz.

WOLAN Andrzej (1530-1610)

54. Doctrina ac pietate praestanti Vi[ro] D[omi]no Danieli Nicolaieuio uerbi diu[ini] in Radzieiouia fido Ministro amico charissimo et observando Autor misit.

In. prow.: 1. Instytut Ossolińskiego - piecz.; 2. Impressa XVI saeculi L. Inw. 18070 - zapis na naklejce na górnej okładzinie oprawy [Ossolineum].

Na: Meditatio In Epistolam Divi Pavli Apostoli ad Ephesios..., Wilnae: Impensis Iohannis Szvveikovvscij, In Officina Iacobi Markouicij, 1592; $4^{\circ}$. - E. XXXIII, 248-249; Ossol. XVI hist., 3136b; Piekarski, ded. XVI 142; W 582.

Sygn. LNNBU: CT-II 31665

[Autor nieznany]

55. Magnifico Perillustri et R[evere]ndissimo D[omi]no D[omi]no M[a] $\mathrm{g}$ [ist]ro Christophoro Sowiński S[acrae] $\mathrm{Ph}$ [ilosophiae] Doctori et 
professori \&\&: Almae Univers[itatis] Cracoviensis Generali Rectori D[omi] no Munificentissimo Patrono Amplissimo [... dalej wycięte].

In. prow.: Gwalbert Pawlikowski - piecz.

Na: Scriptum ad Archivvm cordium Inclytoe Nobilitatis Regni Polonice \& Magni Ducatus Lithvanice gratia Novi Poloniarum Regis eligendi, ad Campum Varsaviensem pro 15. Maij Anni Currentis 1697 Congregandae..., [b.m.: b.w., po 15 V 1697]; 2․ - Bibl. Kórnicka 3454, 310145; E. XXVII, 316-317 (nie wymienia autora); Ossol. XVII, 6481.

Sygn. LNNBU: CT-IV 12158

\section{DODATEK. NOTY WŁAŚCICIELI DZIEŁ OFIAROWANYCH IM PRZEZ AUTORÓW}

CENTOFIORINI Ludovico (-1650)

56. Pro Bibliotheca Conventus Minimoru[m] SS. Trin[itat]is ex dono Authoris. In. prow.: 1. Библіотека Митрополита Андрея Шептицкого Ч. инв. 950 Д - eksl.; 2. Библіотека Митропол[итальна] 1467 - eksl.

Na: Sacri Concilij Tridentini Clypevs Contra Horeticor[um] Sagittas..., Romæ: Typis Sacræ Congreg[atio]nis de Propaganda Fide..., [1647]; 4. COPAC; ICCU.

Sygn. LNNBU: CT-III 15707

JABŁONOWSKI Józef Alexander (1711-1777)

57. Present de S[on] A[ltesse] M[on]s[ei]g[neu]r le Prince Auteur ce 8 Aout 1761. In. prow.: 1. Czarnecki / Gogolewo - rps; 2. Biblioteka Fundacyi W. Hr. Baworowskiego - piecz.

Na: Heraldica To iest Osada Kleynotow Rycerskich..., We Lwowie: w Drukarni J. K. M. Coll. Soc. Jesu, [1752]; 4 . - E. XVIII, 349.

Sygn. LNNBU: CT-II 75420

JAROCKI Ignacy (1742-1802)

58. Hic Liber dono oblatus P[at]ri S[ophronio] Opuski ab autore ejusdem Libri. qui erat Professor in [... zamazane] 1791. die 10 april[is].

In. prow.: Бібліотека ОО. Василиян у Львові - eksl.

Na: De Laudibus Optimce Et Maximce Principis Magnce Marice Theresice..., Leopoli: Typis Viduæ Josephæ Piller..., [1781]; 8 . - E. XVIII, 489.

Sygn. LNNBU: CT-I 92857 
MONTOLIEU Isabelle de (1751-1832)

59. From the Translator Maria Henrietta Montolieu.

In. prow.: 1. J.S. Michałowska - rps; 2. Bibliot. Ossolin. - piecz.; 3. Biblioteka Ossolińskich / N 112837 - eksl.

Na: Delille, Jacques (1738-1813), The Gardens, A Poem. Translated From The French Of The Abbé De Lille [by Mrs Montolieu]..., London: Printed By T. Bensley..., 1798; $4^{\circ}$. - BNF; COPAC.

Montolieu jest thumaczką tego dzieła.

Sygn. LNNBU: CT-IV 26809

PEŠINA z Čechorodu Tomáš Jan (1629-1680)

60. P[atri] Ioannis Alexij Czapek ab ipso Reverendissimo D[omi]no D[omino] (tituli) Authore dono acceptus 16779 Maij.

In. prow.: 1. I.A.C. [= Ioannes Alexius Cžapek] / 1677 - supereksl. napisowy;

2. Supra scripti testamentarius haeres obtulit $\mathrm{R}$ [everen]dissimo $\mathrm{D}$ [omino] Michaeli Benz - rps; 3. Ex libris Michaelis Benz - rps; 4. Nunc fr[atr]is Wenceslai Kerzinger Ord[inis] Praed[icatorum] emptus A[nno] 1697 - rps; 5. Z Księgozbioru Zygmunta Czarneckiego - eksl., piecz. herb.; 6. Biblioteka Fundacyi W. Hr. Baworowskiego - piecz.; 7. Biblioteka W.B. [= Wiktor Baworowski] - piecz.; 8. Opus rarum [...] - rps; 9.2 f. 15 x. - rps (cena).

Na: Mars Moravicus. Sive Bella Horrida Et Cruenta, Seditiones, Tumultus, Prcelia, Turbce..., Pragæ: Typis Joannis Arnolti de Dobroslawina, [po 17 III] 1677; $2^{\circ}$. - Bibl. Kórnicka; ICCU.

Sygn. LNNBU: CT-IV 81499

POSZAKOWSKI Jan (1684-1757)

61. Collegii Cracoviensis ad S[anctum] Petrum Societ[atis] Jesu ab auctore oblatus 1741.

In. prow.: 1. Biblioteka Chrzanowskich. Moroczyn-piecz:; 2. Biblioteka Poturzycka J. W. D. [= Józefa i Włodzimierza Dzieduszyckich] - piecz.; W.D. [= Włodzimierz Dzieduszycki] - piecz.; 3. Gwalbert Pawlikowski - piecz.

Na: Kalendarz Jezuicki Większy na Rok Przestępny [1740]..., Vilnæ: Typis Sacræ Reg. M. Academicis S. J., [1740]; 4 . - E. XXV, 121.

Sygn. LNNBU: CT-II 75794/2 egz.

RADLIŃSKI Jakub Paweł (ok. 1680-1762)

62. Collegii [... zamazano] 1752; / Collegii Cracoviensis S[ocietatis] J[esu] ad S[anctum] Petrum. Ex dono auctoris.

In. prow.: Gwalbert Pawlikowski - piecz. 
Na: Trophace Immaculatce Conceptionis, Beatissimce Virginis Mariae..., Cracoviæ: Typis Michaelis Dyaszewski, 1751; 4 . - E. XXVI, 36-37.

Sygn. LNNBU: CT-II 7266

RYCHLICKI Andrzej z Uniejowa (ok. 1561-1616)

63. R[evere]ndiss[imus] D[ominus] Andreas Rychlicki Suffraganeus Posnan[iensis] eiusdem libri Auctor Conventui Posnan[iensi] Fr[atr]um Ord[inis] Praed[icatorum] dedit A[nno] D[omini] 1616 die 22. Novem[bris]. In. prow.: 1. Edvardus Kropiwnicki praepositus Pempovieckj - rps; 2. Zygmunt Czarnecki - piecz.; 3. Z Księgozbioru Zygmunta Czarneckiego - eksl.; 4. Biblioteka Fundacyi W. Hr. Baworowskiego - piecz.

Na: Divvs Pavlvs Apostolvs, et Ivdas Iscariotes, Proditor..., Wircebvrgi: Ex Officina Typographica Henrici Aquensis, 1591; 4 . - E. XXVI, 513; BJ16 R 676; BJ Pol. 2140; Kotula 55; W 571.

Sygn. LNNBU: CT-II 76514

WEYER Johannes (1597-1675)

64. Ex libr[ris] Andr[eae] Leszczynski ab authore illi datus Pragae.

In. prow.: 1. Collegij Stanislaop[oliensis] Soc[ietatis] Jesu - rps; 2. Бібліотека монастиря ОО. Василіян у Львові - piecz.

Na: Theophilus Se Spiritu Renovans Juxta directionem S. Ignatii Societatis Jesu Fundatoris In Libello Exercitiorum spiritualium... [P. 1-2], Augustæ Vindelicorum: Apud Simonem Utzschneiderum, 1668; 8 . - BNF; VD 17 12:105531L.

Sygn. LNNBU: CT-I 101359

WIECZORKOWSKI Michał Ignacy (1673-1750)

65. Mam tę ksiąszke od $\mathrm{P}$ [ana] J[ego] M[oś]ci Xiędza Michała Wieczorkowskiego Oyca W Bogu Ktoremu niech P[an] Bog Sam zapłaci wielkiem pomyslnem dobrem. Z[akonnica] Brygida Uleyska naiwieksza Grzesznia ZROSB [= Zakonu Reguły Ojca Świętego Benedykta].

In. prow.: 1. Zoffiey Brygidy Uleyskiej ZROSB K L W SS [= Zakonu Reguły Ojca Świętego Benedykta Konwentu Lwowskiego Wszystkich Świętych] rps; 2. Nalepka na grzbiecie biblioteki benedyktynek lwowskich.

Na: Segneri, Paolo, Manna Duszy Albo Cwiczenia się Duchowne... [Cz. 2], W Sandomierzu: w Drukarni J. K. M. Col. Soc. Jesu, [1732]; $4^{\circ}$. - E. XXVII, 345, XXXII, 448; Gwioździk 29m.

Wieczorkowski jest tłumaczem tego dzieła.

Sygn. LNNBU: CT-II 104521/2/2 egz. 
66. Te Xiążke mam Darowano od J[ego] M[oś]ci Xiędza Wieczorkowskiego S[ocietatis] J[esu] / E[lżbieta] Dahlken Z.R.O.S.B. [= Zakonu Reguły Ojca Świętego Benedykta].

In. prow.: 1. Katarzyna Abundancya Ruzycka Z: R: S: O: B [= Zakonu Reguły Świętego Ojca Benedykta] - rps; 2. Nalepka na grzbiecie biblioteki benedyktynek lwowskich.

Na: egz. dzieła wyżej wymienionego.

Wieczorkowski jest thumaczem tego dzieła.

Sygn. LNNBU: CT-II 7688/3/3 egz.

WILKINOWICZ Ignacy (1690-1757)

67. 1743. Ex Bibliotheca Alum[natus] Viln[ensis] / à R[everendo] $\mathrm{P}$ [atre] Ignatio Wilkinowicz S[ocietatis] J[esu] R[egente] A[lumnatus] P[ontificis] V[ilnensis] donatus 1743. 21 bris.

Na: Tractatus Theologicus De Deo Uno \& Trino..., [Wilno]: Typis S. R. M. Academicis Vilnen. Soc. Jesu, [1739]; 4․ - E. XXXIII, 13.

Sygn. LNNBU: CT-II 104468/3 egz.

\section{WYKAZ SKRÓTÓW BIBLIOGRAFICZNYCH}

Adams - Catalogue of books printed on the continent of Europe, 1501-1600 in Cambridge Libraries. Vol. 1-2, comp. H. M. Adams, London 1967.

Bibl. Kórnicka - Biblioteka Kórnicka PAN, [online] http://www.bkpan.poznan.pl/ [dostęp 11.10.2018].

BJ16 - Catalogus librorum saeculi XVI qui in Bibliotheca Iagellonica Cracoviensis asservantur: BJ 16. T. 1-8, curavit M. Malicki, Baden-Baden 2002-2007.

BJ Pol. - Katalog poloników XVI wieku Biblioteki Jagiellońskiej. T. 1-3, red. M. Malicki, E. Zwinogradzka, Kraków 1992-1995.

BNF - Bibliothèque Nationale de France, [online] http://www.bnf.fr/ [dostęp 11.10.2018]. COPAC - Copac National, Academic and Specialist Library Catalogue, [online] http:// copac.ac.uk/ [dostęp 11.10.2018].

E. - K. Estreicher, Bibliografia Polska. Cz. 3: Stólecie XV-XVIII. T. 12-36, Kraków 18912013.

GBV - Gemeinsamer Verbunkatalog, [online] http://gso.gbv.de/ [dostęp 11.10.2018].

Gwioździk - J. Gwioździk, Księgozbiór benedyktynek lwowskich klasztoru pw. Wszystkich Świętych: katalog starych druków, Katowice 2004.

ICCU - Catalogo del Servizio Bibliotecario Nazionale, [online] http://opac.sbn [dostęp 11.10.2018]. 
Kotula - R. Kotula, Właściciele rękopisów i starodruków zbiorów wilkopolskich Z. Czarneckiego mieszczacych się obecnie w «Baworovianum» we Lwowie, Lwów 1929.

ONB - Osterreichische Nationalbibliothek, [online] http://onb.ac.at [dostęp 11.10.2018].

Ossol. XVI - Katalog starych druków Biblioteki Zakładu Narodowego im. Ossolińskich. Polonica wieku XVI, z materiałów rejestracyjnych zebr. zespół. pod kierownictwem K. Zatheya. oprac. M. Bohonos, Wrocław 1965.

Ossol. XVI hist. - Katalog druków XVI wieku z historycznej kolekcji Ossolineum, pod red. D. Sidorowicz-Mulak; zbiory wrocławskie oprac. A. Franczyk-Cegła, M. Minkowska, G. Rolak; zbiory lwowskie oprac. I. Kachur, Wrocław 2017.

Ossol. XVII - Katalog starych drukow Biblioteki Zakładu Narodowego im. Ossolińskich. Polonika wieku XVII. T. 1-9, oprac. B. Górska, W. Tyszkowski, G. Rolak, Wrocław 1991-1997.

Piekarski, ded. XVI - K. Piekarski, Rękopiśmienne dedykacje autorskie XVI wieku, „Przegląd Biblioteczny” 1929, R. 3, z. 2, s. 173-190.

Piekarski, rec. - K. Piekarski, Rudolf Kotula: Właściciele rękopisów i starodruków zbiorów wielkopolskich Z. Czarneckiego, mieszczacych się obecnie w «Baworovianum» we Lwowie [recenzja], „Przegląd Biblioteczny” 1929, R. 3, z. 3, s. 388-415.

VD 16 - Das Verzeichnis der im deutschen Sprachraum erschienenen Drucke des 16. Jahrhunderts, [online] http://www.vd16.de/ [dostęp 11.10.2018].

VD 17 - Das Verzeichnis der im deutschen Sprachraum erschienenen Drucke des 17. Jahrhunderts, [online] http://www.vd17.de/ [dostęp 11.10.2018].

W - T. Wierzbowski, Bibliographia Polonica XV ac XVI ss. Vol. 1-3, Varsovia 18891894.

\section{INDEKS ALFABETYCZNY ADRESATÓW DEDYKACJI}

Andrzejewicz Józef (1665-1739), ks., jezuita, profesor filozofii i teologii, rektor kolegiów, w latach 1735-1739 prepozyt domu profesów w Krakowie - 26.

Badeni Marcin (1762-1824), polski działacz polityczny i gospodarczy, sekretarz królewski, bratanek Stanisława Augusta Poniatowskiego; szambelan JKM Stanisława Augusta - 51 .

Bassai (Basai, Basaeus, Bassaeus, Bazaeusz) Wojciech z Szczebrzeszyna k. Zamościa (zm. po 1570), kanonik regularny krakowski, wierszopis, gramatyk - 17 .

Bazylianie - Buczacz (Monasterium Buczaczensis PP. Basilianorum) - 43.

Bernardyni - Przeworsk (Conventus Prevorscensis PP. Regularis observantiae S. Francisci) -4 .

Bogucicki Józef Jan Kanty (1747-1798), ks., doktor filozofii i teologii, sekretarz Szkoły Głównej Koronnej, członek Towarzystwa do Ksiąg Elementarnych, historyk Kościoła - 5.

Burgolt (Bourgault?) Daniel - 13.

Chodorski Adam (1642-1703), ks., jezuita, teolog, profesor, prefekt szkół - 7.

Crull[...?] Johann, radca prawny - 38 . 
Cžapek Joannes Alexius (Čapek Jan Aleš, 1640-1695), czeski katolicki ksiądz, tłumacz $\mathrm{z}$ łaciny, pisarz religijny, publicysta -60 .

Dahlken Anna Elżbieta (1719-1791), benedyktynka lwowska - 66.

Dobrski Antoni (1681-1756), ks., jezuita, profesor, prefekt szkół, rektor w Gdańsku, Lublinie w latach 1738-1741 i Krakowie (kolegium) - 29.

Dominikanie - Lwów (Conventus Leopoliensis PP. Praedicatorum) - 3, - Poznań (Conventus Posnaniensis Fr. Ord. Praedicatorum) - 63.

Gierkowski [?] Jan, pułkownik - 27.

Glicjusz Marcin (Glicius Martinus) z Pilzna (1528-1591), doktor filozofii i teologii, profesor i szesnastokrotny rektor Akademii Krakowskiej, kaznodzieja, kanonik wrocławski i krakowski - 23.

Hacki Michał Antoni (1630-1703), duchowny katolicki, dyplomata i mecenas sztuki, w latach 1683-1703 opat klasztoru cystersów w Oliwie - 6 .

Jabłonowski Roch Michał (ok.1712-1780), kasztelan wiślicki, senator, starosta korsuński-25.

Jabłonowski Stanisław Jan (1634-1702), kasztelan krakowski, hetman wielki koronny $-19$.

Jakobejus (Jakubczyk) Stanisław z Kurzelowa (Stanislaus Jacobeius Cureloviensis, 1540-1612), matematyk i astrolog, doktor i profesor medycyny w Akademii Krakowskiej -40 .

Jałowicki (Jełowicki) Jan Stanisław Bożeniec, ks., kanonik i surogat łucki, proboszcz ostrogski rzymskokatolicki w latach 1682-1699 - 33.

Jankowski Józef (1711-po 1780), ks., jezuita, profesor i prefekt szkół w Nieświeżu, Pińsku i Płocku, rektor Collegium Nobilium i Akademii w Wilnie - 36.

Jezuici - Jarosław (Collegium Jaroslaviense S.J. ad BVM) - 41, 48, - Kraków (Collegium Cracoviense S.J. ad S. Petrum) - 61, 62, - Wilno (Alumnatus Vilnensis) - 67.

Joannes, minister zboru ewangielickiego w Żołyni (pow. łańcucki) - 24.

Karczewski Aleksander (1709-1780), ks., jezuita, prefekt szkół, profesor i rektor kolegiów jezuickich w Łucku, Barze i Krzemieńcu - 21.

Kasprowicz Sebastian, rajca biecki, XVII w. - 30.

Kaznowski Stanisław (1665-1724), ks., jezuita, prokurator spraw spornych prowincji, rektor w Krośnie i Piotrkowie - 16.

Kneè Józef Gabriel (-po 1822), doktor medycyny, fizyk, cesarsko-królewski radca, profesor, dziekan wydziału medycyny Uniwersytetu Lwowskiego - 15.

Koncewicz (Konczewicz) Innocenty (1753 - po 1806), ksiądz unicki, bazylianin, kaznodzieja przy kościele bazyliańskim św. Anny w Krakowie (do 1797 r.), autor prac homiletycznych - 52.

Łaski Hieronim (1496-1541), polski polityk i dyplomata, bratanek prymasa Jana Łaskiego st. -12 .

Łaski Jan st. (1455-1531), arcybiskup gnieźnieński i prymas Polski - 11.

Leszczyński Andrzej z Leszna (-1681), kanonik gnieźnieński, proboszcz łowicki, koadiutor, opat czerwiński - 64 . 
Lewiński - 44.

Małżycki Jan (1681-1745), ks., jezuita, misjonarz ludowy w Jabłonowie, Międzyrzeczu, Nastasowie, Równem i Ruszatyczach - 53.

Michałowska J.S., XVIII w. - 59.

Mikołajewski Daniel (1560-1633), polski duchowny i teolog reformowany, senior zborów na Kujawach, współtłumacz „Biblii gdańskiej”, w 1591 r. został ordynowany na ministra w Radziejowie - 54 .

Minimici - Rzym (Conventus Minimorum SS. Trinitatis) - 56.

Naramowski Mikołaj (1669-1738), ks., jezuita, prefekt i profesor kolegiów jezuickich, rektor w Łucku, Jarosławiu, Krakowie i Poznaniu, autor utworów dramatycznych dla teatru szkolnego -22 .

Nereziusz Jan Hieronim (Hieronym, -1790), ks., bazylianin, pedagog, rektor kolegium buczackiego, opat brasławski - 32 .

Olechowicz Józef (1665-1699), ks., jezuita, misjonarz w Nowym Korczynie, profesor retoryki w Krośnie i Kaliszu - 35.

Opuski Sophronius (1758-1836), ks., bazylianin, superior klasztoru hoszowskiego i podhoreckiego, administrator prowincji galicyjskiej - 58 .

Prosiński [?] Stanisław (XVI w.) - 37.

Potocki Ignacy (1750-1809), mąż stanu, pisarz wielki litewski, marszałek nadworny litewski, członek Komisji Edukacji Narodowej - 50.

Queck (Kweck, Kweyk, Kwek) Walenty (1641-1725), jezuita, pedagog, prowincjał prowincji polskiej, asystent generała zakonu -9 .

Rektor kolegium pijarskiego w Warszawie w 1719 r. -42.

Rolascius [?] Ioannes -31 .

Rudnicki Jakub Przemysław (1585-1650), ks., jezuita, wychowawca króla Jana Kazimierza, profesor i rektor szkół, prowincjał - 20.

Rzewuski Wacław Piotr (1706-1779), starosta kruszwicki, hetman wielki koronny, poeta, pisarz polityczny, mecenas sztuki, bibliofil i kolekcjoner - 28 .

Schmerling von, baron, minister pełnomocny na dworze francuskim -49 .

Schrader Daniel (1642-1693), ławnik i rajca miasta Gdańska - 2.

Siewierski Franciszek Ignacy (1644-1710), ks., jezuita, superior w Chojnicach, prokurator prowincji w Krakowie, rektor w Łucku i Krośnie - 10, 18.

Sowiński Krzysztof Franciszek (1642-1699), doktor teologii, profesor i rektor Uniwersytetu Krakowskiego, dziekan kapituły kolegiaty św. Floriana w Krakowie - 55.

Swieten Gerard van (1700-1772), lekarz cesarzowej Marii Teresy, uczeń holenderskiego lekarza i humanisty Hermana Boerhaave - 46.

Trynitarze - Kraków (Conventus Cracoviensis PP. Ordinis Discalceatorum Sanctissimae Trinitatis Redemptionis Captivorum) - 14.

Ulejska Zofia Brygida (-1775), benedyktynka lwowska - 65 .

Ustrzycki Bazyli (1715-1751), stolnik żydaczowski i przemyski, kasztelan przemyski - 47.

Wolkenstein-Rodenegg Sigismund, baron (1554-1624) - 39. 
Zacherla Sebastian, ks., jezuita - 34 .

Żółkiewski Bernard (1662-1729), ks., jezuita, prefekt szkół i profesor w różnych kolegiach jezuickich -8 .

[Adresaci nieokreśleni] - 1, 45, 57.

\section{INDEKS PROWENIENCJI}

Baworowski Wiktor (Biblioteka Fundacyi W. Hr. Baworowskiego) - 17, 23, 24, 31, 37 , 40, 42, 57, 60, 63.

Bazylianie - Buczacz (Bibliotheca Scholarum Buczaczensium) - 43; Dobromil (Conventus Dobromiliensis OSBM) - 47; Krechów (Бібліотека ОО. Василіян у Крехові) - 43, 47; Lwów (Monasterium O. S. Basilii Magni Leopoliensis, Бібліотека монастиря ОО. Василіян у Львові, Центральна Василіянська бібліотека у Львові) - 1, 11, 12, 32, 41, 48, 58, 64.

Benedyktynki - Lwów - 53, 65, 66.

Benz Michael - 60 .

Biergiel Józef Julian (1819-1885), doktor filozofii, pastor parafii w Słucku, wice-superintendent kościołów ewangelicko-reformowanych na Białorusi i Wileńszczyźnie, bibliofil - 24.

Chmel Jerzy (1747-1806), chirurg, profesor weterynarii Uniwersytetu Lwowskiego - 46.

Chrzanowscy (Biblioteka Chrzanowskich, Moroczyn), biblioteka założona przez Edwarda Chrzanowskiego (1843-1922), częściowo przekazana w 1925 r. Ossolineum we Lwowie (ok. 5000 wol.) w depozyt wieczysty - 29, 45, 61.

Czarnecki Zygmunt (1823-1908), kolekcjoner, bibliofil, numizmatyk, zgromadził piękny księgozbiór w Rusku i Gogolewie - 24, 31, 37, 42, 57, 60, 63.

Czartoryscy (Biblioteka XX. Czartoryskich), biblioteka założona przez Adama Kazimierza (1734-1823) i jego żonę Izabelę z Flemmingów (1746-1835) w Warszawie i w Puławach -23.

Dominikanie - Lwów (Biblioteka Księży Dominikanów Lwowskich) - 3 .

Drozdowicz Tomasz (1788-1864), jezuita, misjonarz w Irkucku, budowniczy konwiktu w Tarnopolu, zakrystian i infirmarz w Tyńcu i Nowym Sączu - 36.

Dzieduszyccy (Biblioteka Poturzycka J.W.D. [= Józefa i Włodzimierza Dzieduszyckich]), biblioteka założona przez Józefa Kalasantego Dzieduszyckiego (1776-1847), w 1857 r. przeniesiona przez syna Włodzimierza (1825-1899) do Lwowa - 25, 28, 50,61 .

Dzierzkowski Józef Dobek (1764-1830), adwokat lwowski, polityk, wicemarszałek Stanów Galicyjskich, doktor filozofii Uniwersytetu Lwowskiego, bibliofil - 28.

Gorajska Maryanna, benedyktynka - 53 .

Jabłonowski Franciszek Ksawery (1770-1817), kanonik katedralny kujawski, syn Rocha Michała Jabłonowskiego (ok. 1712-1780) - 25. 
Januszowski Jan (-ok. 1855/1857), komornik lwowski, kolekcjoner - 25.

Jezuici - Chyrów (Collegium Chyroviense Societatis Jesu) - 26, 36; Łuck (Collegium Luceoriense Societatis Jesu) - 7, 8, 16; Nowy Sącz (Collegium Neo-Sandecense Societatis Jesu) - 36; Stanisławów (Collegium Stanislaopoliense Societatis Jesu) 64; Stara Wieś (Collegium Societatis Jesu Staraviesiae) - 36; Tarnopol (Collegium Tarnopolitanum Soc. Jesu) - 26.

Kerzinger Wencesław - 60 .

Kneè Józef Gabriel (-po 1822), doktor medycyny, fizyk, dziekan fakultetu medycznego Uniwersytetu Lwowskiego - 15.

Krausneker Peter (1766-1842), lekarz, profesor anatomii i rektor Uniwersytetu Lwowskiego -15 .

Kropiwnicki Edward (1798-1866), proboszcz w Pępowie - 63.

Łopatyn (pow. złoczowski), biblioteka parochialna - 14 .

Łaski Jan mł. (1499-1560), humanista, działacz reformacyjny, bratanek arcybiskupa J. Łaskiego st. (1455-1531) - 11, 12.

Łaszczewski Sylwester (1726-1783), ks., bazylianin, profesor szkół bazyliańskich, rektor kolegium w Hoszczy, superior w Wicynie, Trębowli i Krechowie - 1 .

Meldon M. -25.

Michałowska J.S. -59.

Ossolineum (Instytut Ossolińskiego, Biblioteka Ossolińskich), biblioteka założona przez bibliografa, historyka i bibliofila Józefa Maksymiliana Ossolińskiego (1748-1826) w Wiedniu, po jego śmierci przewieziona do Lwowa - 15, 46, 49, 54, 59.

Petruszewicz Antoni (1821-1913; Музей А.С. Петрушевича), ukraiński duchowny greckokatolicki, historyk, filolog, etnograf, działacz społeczny, kolekcjoner - 14 .

Pawlikowski Gwalbert (1792-1852), polityk, bibliofil, założyciel biblioteki w Medyce, przewiezionej do Lwowa, w 1921 r. przekazanej do Ossolineum - 2, 5, 13, 20, 27 , $30,39,55,61,62$.

Radzikowski Józef - 2.

Różycka (Ruzycka) Katarzyna Abundancja (-1833), lwowska benedyktynka, ksieni klasztoru we Lwowie, nauczycielka i prefektka szkoły - 66.

Słotwiński Wojciech (Albert), ks., dominikanin, w latach 1750-1753 przeor kościoła pw. św. Dominika w Pińsku, prowincjał prowincji ruskiej S. Hiacynta - 36.

Studion (Книгозбірня „Студіону” у Львові), biblioteka klasztoru studytów we Lwowie, założona w 1909 r. przez metropolitę lwowskiego i halickiego Andrzeja Szeptyckiego -51 .

Szeptycki Andrzej (1865-1944), arcybiskup, metropolita greckokatolicki, teolog, działacz społeczny, kolekcjoner - 56 .

Wiszniewski Adam - 45.

Wronowski Stanisław (1733-1839), radca cesarsko-królewski Trybunału I Instancji we Lwowie, członek Stanów Galicyjskich, bibliofil, kolekcjoner, darczyńca Ossolineum $-46,49$. 


\section{WYKAZ NUMERÓW DEDYKACJI WEDŁUG WIEKÓW}

XVI w.

$11,12,17,23,24,37,39,40,54$.

XVII w.

$1,2,3,6,7,8,9,10,18,19,20,30,31,33,34,35,38,55,56,60,63,64$.

XVIII w.

$4,5,13,14,15,16,21,22,25,26,27,28,29,30,36,41,42,43,44,45,46,47,48,49$, $50,51,52,53,57,58,59,61,62,65,66,67$.

\section{ILUSTRACJE}

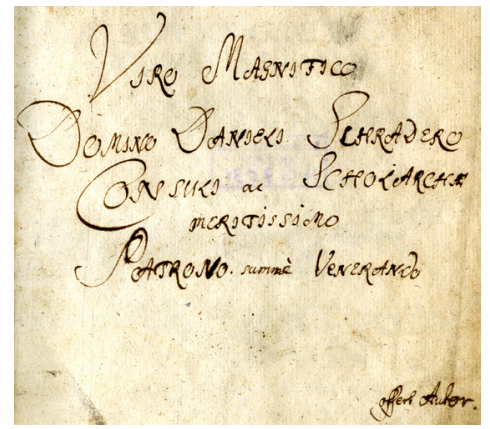

Fot. 1. Dedykacja Adriana Beiera dla Daniela Schradera, poz. 2.

Zdjęcie: Natalia Lew

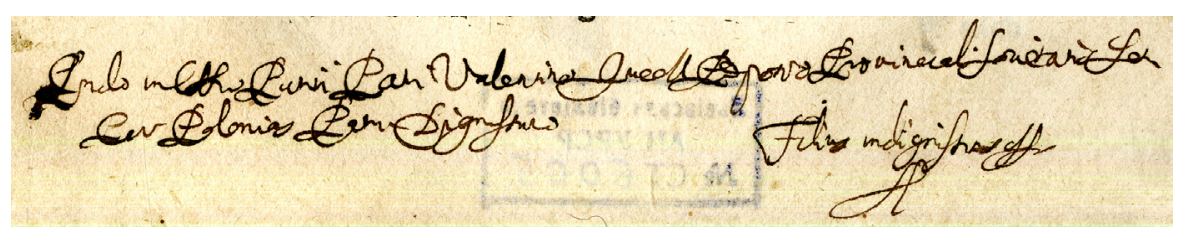

Fot. 2. Dedykacja Aleksandra Elisza dla Walentego Quecka, poz. 9.

Zdjęcie: Natalia Lew

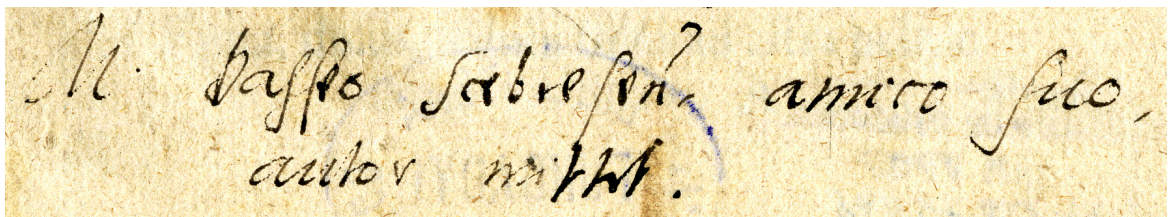

Fot. 3. Dedykacja Stanisława Herbesta dla Wojciecha Bassai z Szczebrzeszyna, poz. 17. Zdjęcie: Natalia Lew 


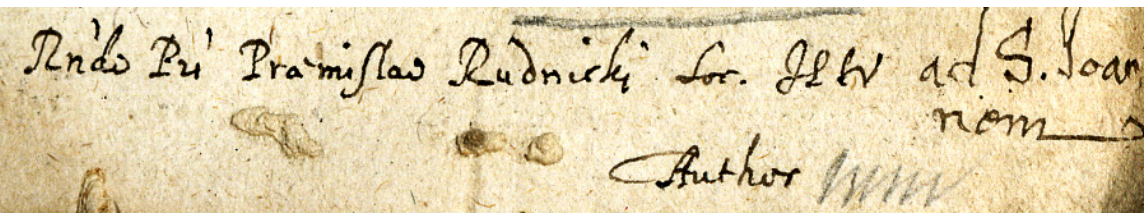

Fot. 4. Dedykacja Tomasza Klage dla Jakuba Przemysława Rudnickiego, poz. 20.

Zdjęcie: Natalia Lew

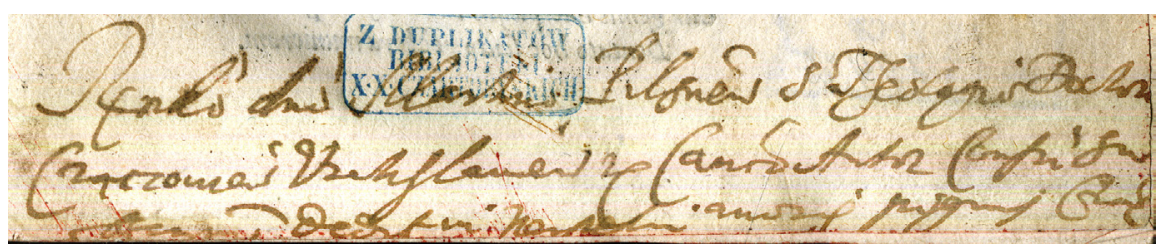

Fot. 5. Dedykacja Macieja Kłodzińskiego dla Marcina Glicjusza z Pilzna, poz. 23. Zdjęcie: Natalia Lew

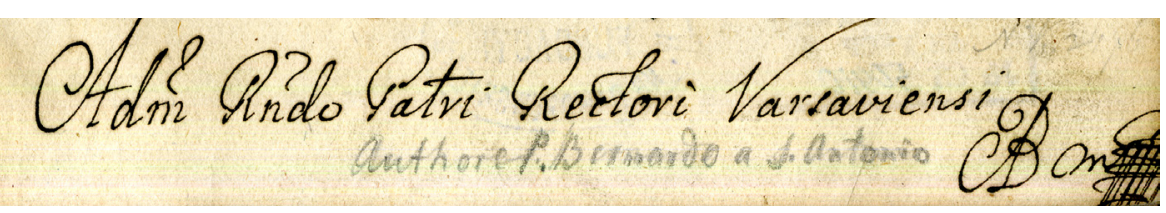

Fot. 6. Dedykacja Antoniego Sienkiewicza dla rektora kolegium w Warszawie, poz. 42. Zdjęcie: Natalia Lew

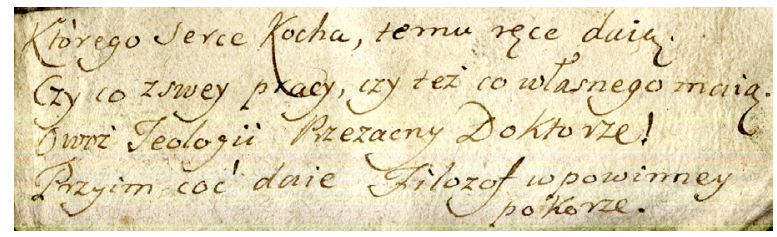

Fot. 7. Dedykacja Augustyna Sławińskiego dla anonima, poz. 45. Zdjęcie: Natalia Lew 


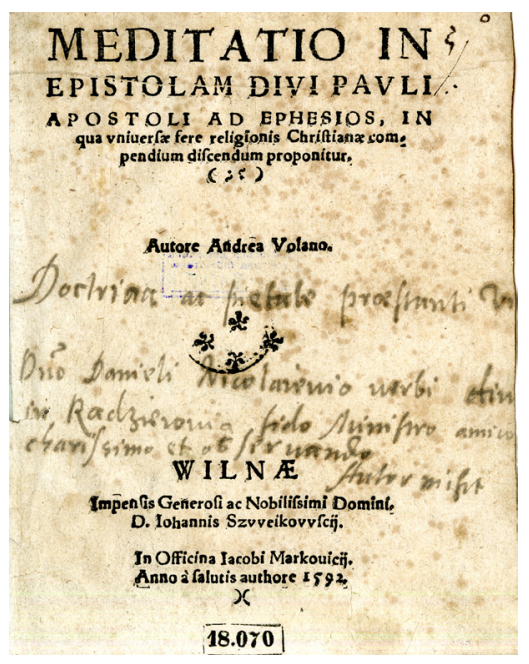

Fot. 8. Dedykacja Andrzeja Wolana dla Daniela Mikołajewskiego, poz. 54. Zdjęcie: Natalia Lew

\section{Bibliografia}

Ciborowska-Rymarowicz I., Orientalista Tadeusz Krusiński (1675-1757) i egzemplarze jego prac w bibliotekach klasztornych i prywatnych XVIII wieku, „Bibliotekarz Podlaski” 2015, R. 16, nr 1, s. 11-34.

Ціборовська-Римарович I.О., Сходознавещьь Тадей Крусинський $i$ його праці у фондах Національної бібліотеки України імені В. І. Вернадського, „Київські Полоністичні Студії” 2003, t. 4, s. 123-148.

Kachur I., Z historii bibliotek renesansowych - dar Erazma z Rotterdamu dla arcybiskupa Jana Łaskiego, [w:] Książka dawna i jej właściciele. Zbiór studiów. T. 2, pod red. D. Sidorowicz-Mulak, A. Franczyk-Cegły, Wrocław 2017, s. 17-32.

Kosiński J.A., Szczepaniec J., Rękopiśmienne dedykacje autorskie XVI-XVIII wieku w zbiorach starych druków Biblioteki Ossolineum, „Ze Skarbca Kultury” 1964, nr 16, s. 187-213.

Piekarski K., Dedykacje autorskie w zbiorze druków XVI wieku Biblioteki Kórnickiej, „Silva Rerum” 1927, t. 3, z. 11-12, s. 188-190.

Sajna B., Zychowiczowa M., Rękopiśmienne dedykacje autorskie w zbiorze poloników XVI wieku w Bibliotece Narodowej, [w:] Studia ofiarowane profesor Alodii Kaweckiej-Gryczowej w 85-lecie urodzin. [T.] 1, [kom. red. P. Buchwald-Pelcowa i in.], Warszawa 1991, s. 63-76.

Sobol R., «Korespondencja Ignacego Krasickiego», z papierów Ludwika Bernackiego wydali i opracowali Zbigniew Goliński, Mieczysław Klimowicz, Roman Wołoszyński, pod redakcją Tadeusza Mikulskiego... [recenzja], „Pamiętnik Literacki” 1960, t. 51, z. 4, s. 481-495.

Wittyg W., Ex-libris'y bibliotek polskich. XVI-XX wieku, Warszawa 1903. 